\title{
Recombinant production of the antibody fragment D1.3 scFv with different Bacillus strains
}

Antonia Lakowitz ${ }^{1,2,3}$, Rainer Krull ${ }^{1,2,3}$ and Rebekka Biedendieck ${ }^{3,4^{*}}$

\begin{abstract}
Background: Different strains of the genus Bacillus are versatile candidates for the industrial production and secretion of heterologous proteins. They can be cultivated quite easily, show high growth rates and are usually non-pathogenic and free of endo- and exotoxins. They have the ability to secrete proteins with high efficiency into the growth medium, which allows cost-effective downstream purification processing. Some of the most interesting and challenging heterologous proteins are recombinant antibodies and antibody fragments. They are important and suitable tools in medical research for analytics, diagnostics and therapy. The smallest conventional antibody fragment with high-affinity binding to an antigen is the single-chain fragment variable (scFv). Here, different strains of the genus Bacillus were investigated using diverse cultivation systems for their suitability to produce and secret a recombinant scFv.
\end{abstract}

Results: Extracellular production of lysozyme-specific scFv D1.3 was realized by constructing a plasmid with a xyloseinducible promoter optimized for Bacillus megaterium and the D1.3scFv gene fused to the coding sequence of the LipA signal peptide from B. megaterium. Functional scFv was successfully secreted with B. megaterium MS941, Bacillus licheniformis MW3 and the three Bacillus subtilis strains 168, DB431 and WB800N differing in the number of produced proteases. Starting with shake flasks $(150 \mathrm{~mL})$, the bioprocess was scaled down to microtiter plates $(1250 \mu \mathrm{L})$ as well as scaled up to laboratory-scale bioreactors ( $2 \mathrm{~L})$. The highest extracellular concentration of D1.3 scFv $\left(130 \mathrm{mg} \mathrm{L}^{-1}\right)$ and highest space-time-yield $\left(8 \mathrm{mg} \mathrm{L}^{-1} \mathrm{~h}^{-1}\right.$ ) were accomplished with B. subtilis WB800N, a strain deficient in eight proteases. These results were reproduced by the production and secretion of a recombinant penicillin $\mathrm{G}$ acylase (Pac).

Conclusions: The genus Bacillus provides high potential microbial host systems for the secretion of challenging heterologous proteins like antibody fragments and large proteins at high titers. In this study, the highest extracellular concentration and space-time-yield of a recombinant antibody fragment for a Gram-positive bacterium so far was achieved. The successful interspecies use of the here-designed plasmid originally optimized for B. megaterium was demonstrated by two examples, an antibody fragment and a penicillin $\mathrm{G}$ acylase in up to five different Bacillus strains.

Keywords: Bacillus megaterium, Bacillus licheniformis, Bacillus subtilis, Antibody fragment D1.3 scFv, Recombinant, Secretion, Proteases, Scale-up cultivation, Scale-down cultivation

\section{Background}

Members of the genus Bacillus are rod-shaped aerobic or facultatively anaerobic, Gram-positive bacteria $[1,2]$. This genus is one of the most diverse groups of microorganisms and its representatives are widely distributed

\footnotetext{
*Correspondence: r.biedendieck@tu-braunschweig.de

${ }^{3}$ Braunschweig Centre of Systems Biology (BRICS), Technische Universität

Braunschweig, Rebenring 56, 38106 Braunschweig, Germany

Full list of author information is available at the end of the article
}

in soil, air and water [1, 2]. Different Bacillus strains have been developed and engineered as industrial producers of natural enzymes such as alkaline proteases (Bacillus clausii), $\alpha$-amylase (Bacillus licheniformis) and $\beta$-glucanase (Bacillus subtilis) [3], antibiotics like bacitracin (B. licheniformis) [4], insecticides such as $\delta$-endotoxin (Bacillus thuringiensis) [5, 6], vitamin $\mathrm{B}_{2}$ (B. subtilis) [7], the supplement poly- $\gamma$-glutamic acid or ubiquinone biopolymer nanocarriers (B. licheniformis) $[8,9]$. Besides 
natural products, Bacillus strains are great candidates for industrial production and secretion of heterologous proteins due to several advantages. In comparison to eukaryotic systems, their cultivation is simple and their high growth rates lead to short cultivation times. Most Bacillus strains are non-pathogenic and free of exo- and endotoxins. Species like B. subtilis and B. licheniformis even have the generally regarded as safe (GRAS) status $[10,11]$. In addition, these species have the ability to secrete proteins directly into the extracellular medium, resulting in cost-effective downstream purification processing. In contrast, Gram-negative bacteria, like the best-analyzed representative Escherichia coli, accumulate proteins intracellularly and tend to build mostly cell-toxic and insoluble protein accumulations (inclusion bodies). These result in cost-intensive downstream processing due to incorrect protein folding and inefficient disulfide bridge formation $[3,12]$.

The production of proteins of eukaryotic origin in prokaryotic organisms provides one of the biggest challenges of biotechnology. Eukaryotic proteins heterologously produced and secreted with Bacillus are e.g. human interferon alpha (15 $\mathrm{mg} \mathrm{L}^{-1}$, B. subtilis, [13]), growth hormone (200 $\mathrm{mg} \mathrm{L}^{-1}$, B. subtilis, [14]) or epidermal growth factor (240 $\mathrm{mg} \mathrm{L}^{-1}$, Bacillus brevis, [15]). Levels of these heterologous proteins are quite low in comparison to homologous proteins and those of prokaryotic (Gramnegative or -positive) origin, e.g. secreted $\alpha$-amylase with up to $3 \mathrm{~g} \mathrm{~L}^{-1}$ [16]. One major limiting factor is the degradation of the secreted protein by membrane-bound, cell wall-associated or secreted proteases [17]. Proteases constitute the cellular quality control which degrade proteins folded too slowly or incorrectly [18]. Many heterologous proteins are frequently found to be inefficiently and slowly folded compared to the homologous counterparts since they are not coevolved with the host protein production machinery. This might even lead to the exposure of protease-recognition sequences even in correctly folded conformation $[16,19,20]$. To overcome degradation of secreted heterologous proteins, many protease-deficient Bacillus mutants have been successfully constructed and used resulting in more effective extracellular protein production [21].

Some of the most interesting and challenging proteins heterologously produced in prokaryotes are recombinant antibodies and antibody fragments which are important and suitable tools in research and medicine. Their specific antigen binding is used in analytics, in proteome research, in diagnostics of pathogens and toxins and in therapy of inflammatory and tumor diseases [22-24]. A whole immunoglobulin $G$ molecule is a hetero-tetramer with two heavy and two light chains connected by disulfide bridges and intramolecular disulfide bridges for stabilization
[25]. Since their production requires a complicated folding apparatus and an oxidizing environment for disulfide bridge formation, many microbial host systems fail to produce significant amounts of the molecules [26]. In addition, bacterial hosts usually do not accomplish the correct glycosylation of the produced antibodies. However, smaller and simpler antibody fragments with full antigen binding capacity have been developed for research purposes, where biological activity is more important than structural authenticity and correct glycosylation pattern. The smallest conventional antibody fragment with high-affinity binding to an antigen is the single-chain fragment variable $(\mathrm{scFv})$ [27], a heterodimer comprising the antibody heavyand light-chain variable domains connected by a peptide linker and with natural disulfide bonds within the chains to stabilize the molecule [28].

Here, the recombinant production and secretion of the lysozyme-specific antibody fragment D1.3 scFv in $B$. megaterium, B. licheniformis and three B. subtilis strains differing in their protease equipment are presented to demonstrate the interspecies use of the $B$. megaterium plasmid system. For this, the gene encoding His-tagged D1.3 scFv genetically fused to a suitable secretion signal was expressed under the control of a xylose-inducible promoter optimized for recombinant protein production in B. megaterium. Starting with uncontrolled shake flask (150 mL culture volume) cultivations, the bioprocess was scaled down to microtiter plates $(1250 \mu \mathrm{L}$ culture volume), but also scaled up to controlled laboratory-scale stirred tank bioreactors ( 2 L culture volume). Growth, secretion behavior, product titer, product kinetics and space-time-yield (STY) were compared between the different strains and cultivation systems. Finally, these results were reproduced for the production and the secretion of a recombinant penicillin $\mathrm{G}$ acylase (Pac) with a three times higher molecular weight compared to the D1.3 scFv. Pac (EC 3.5.1.11) catalyzes the cleavage of penicillin $\mathrm{G}$ and cephalosporin $\mathrm{G}$ to intermediates important for the production of semi-synthetic $\beta$-lactam antibiotics [29]. It is autocatalytically processed from a single cytoplasmic polypeptide precursor carrying a signal peptide and a spacer peptide and finally correctly folded outside the cell before released to the growth medium [30, 31]. Therefore, $\mathrm{Pac}$ is a challenging candidate for recombinant secretion carried out here with three different Bacillus strains using the same plasmid background as for the recombinant D1.3 scFv.

\section{Results}

\section{Plasmid for the recombinant production and secretion of D1.3 scFv}

The xylose-inducible promoter $\mathrm{P}_{x y l A}$ was originally derived from the B. megaterium strain DSM319. There it 
controls the $x y l A B T$ operon encoding proteins of xylose uptake and metabolism via a divergently encoded repressor protein, termed XylR. $\mathrm{P}_{x y l A}$ was systematically optimized for high yield protein production in $B$. megaterium previously [32]. For the production, secretion and purification of D1.3 scFv in B. megaterium, the corresponding synthetic gene was fused to the coding sequences for the signal peptide of the lipase A of B. megaterium and for a his ${ }_{6}$-tag under control of native $\mathrm{P}_{x y l A}$ before [33]. The employed vector backbone was carrying the oriU, repU and tet $L$ genes from the $B$. cereus plasmid $\mathrm{pBC} 16$ [34] for replication and selection in Bacillus. To now enhance the recombinant production and secretion of D1.3 scFv, the $D 1.3 s c F v$ gene fused to the lipase A signal peptide coding sequence was cloned into a pBC16-derived plasmid carrying the $\mathrm{P}_{x y l A}$, optimized for recombinant protein production in B. megaterium (Fig. 1). Furthermore, this new plasmid pRBBm117 is minimized by around $700 \mathrm{bp}$ to reduce metabolic burden for the production strain [35].

After transformation of B. megaterium MS941, a mutant of DSM319 lacking the main extracellular protease NprM and thus around $98 \%$ of extracellular protease activity [36], the recombinant secretion of D1.3 $\mathrm{scFv}$ was analyzed in $150 \mathrm{~mL}$ shake flask cultivation in minimal medium (Table 1). The oxygen input was realized via orbital shaking movements. The volumetric mass transfer coefficients for oxygen $\left(k_{L} a\right)$ of $30-50 \mathrm{~h}^{-1}$ were assumed $[37,38]$. Growth passed the typical phases of



Fig. 1 Plasmid pRBBm117 for recombinant production of the antibody fragment D1.3 scFv. Popt. optimized xylose-inducible promoter; opt. RBS, optimized ribosome binding site; $s p_{\text {lipA, }}$ signal peptide sequence of B. megaterium extracellular esterase LipA; D1.3scFV, gene for single chain fragment variable (scFv) against lysozyme; $h$ is $_{6}$-tag, synthetic tag for $6 \times$ histidine residues; bla, $\beta$-lactamase gene for ampicillin resistance; ori (pBR322), E. coli origin of replication from plasmid pBR322; oriU (pBC16), B. megaterium origin of replication from plasmid $\mathrm{pBC}$ 16; rep $U$ ( $\mathrm{pBC}$ 16), gene essential for plasmid replication in B. megaterium from plasmid $\mathrm{pBC} 16$; tetL, gene encoding tetracycline efflux pump for tetracycline resistance; $x y / R$, gene encoding xylose repressor
Table 1 Summary of cultivation conditions in microtiter plates, shake flasks and bioreactors

\begin{tabular}{llll}
\hline Parameter & Microtiter plate & Shake flask & Bioreactor \\
\hline $\begin{array}{l}\text { Cultivation volume }[\mathrm{mL}] \\
\begin{array}{l}\text { Shake/stirrer frequency } \\
{\left[\mathrm{min}^{-1}\right]}\end{array}\end{array}$ & 1.25 & 150 & 2000 \\
$\begin{array}{l}\text { Aeration rate }\left[\mathrm{L} \mathrm{min}^{-1}\right] \\
\quad \text { with air }\end{array}$ & - & $130^{\mathrm{b}}$ & 500 \\
$k_{\mathrm{L}}$ a value $\left[\mathrm{h}^{-1}\right]$ & $150-200$ & $30-50$ & 3 \\
$\mathrm{pH}$ value $[-]$ & Unregulated & Unregulated & 6.5 \\
\hline
\end{tabular}

a $3 \mathrm{~mm}$ orbital diameter

b $50 \mathrm{~mm}$ orbital diameter

c Before addition of anti-foaming agent

a batch process (Fig. 2). The addition of $5 \mathrm{~g} \mathrm{~L}^{-1}$ xylose for the induction of recombinant gene expression $2-3 \mathrm{~h}$ after inoculation led to temporarily decreased growth. The specific growth rate $\mu\left[\mathrm{h}^{-1}\right]$ is the proportionality factor between time-dependent change of cell concentration $\mathrm{dX} / \mathrm{dt}\left[\mathrm{g} \mathrm{L}^{-1} \mathrm{~h}^{-1}\right]$ and current cell concentration $\mathrm{X}\left[\mathrm{g} \mathrm{L}^{-1}\right](\mathrm{dX} / \mathrm{dt}=\mu \cdot \mathrm{X})$. It decreased from 0.45 to $0.15 \mathrm{~h}^{-1}$. Growth became accelerated again $\left(0.33 \mathrm{~h}^{-1}\right)$ until the initial $5 \mathrm{~g} \mathrm{~L}^{-1}$ fructose were completely consumed after 16-18 h. Stationary phase was attained with about $2 \mathrm{~g} \mathrm{~L}^{-1}$ of cell dry weight. The secretion of active, correctly folded D1.3 scFv already started during the exponential growth phase while maximal amounts of $8 \mathrm{mg} \mathrm{L}{ }^{-1}$ were detected $4 \mathrm{~h}$ after entering the stationary phase and stayed constant until the end of the cultivation. The production was assumed mixed-growthassociated: the growth-associated biomass-related production yield coefficient $\alpha \equiv \mathrm{Y}_{\mathrm{P} / \mathrm{X}}=0.13 \mathrm{mg}_{\text {scFv }} \mathrm{g}_{\text {cells }}^{-1}$ and the non-growth-associated specific production rate $\beta=0.41 \mathrm{mg}_{\text {scFv }} \mathrm{g}_{\text {cells }}^{-1} \mathrm{~h}^{-1}$ were calculated (Additional file 1: Table S1). During stationary phase, the carbon source fructose was already depleted and the formerly secreted acetate was consumed. The concentration of the inducer xylose stayed constant at a level of $5 \mathrm{~g} \mathrm{~L}^{-1}$ until fructose was exhausted and was only slightly reduced to $>4 \mathrm{~g} \mathrm{~L}^{-1}$ until the end of the cultivation (Additional file 1: Figure S1). Little consumption of xylose by $B$. megaterium MS941 after depletion of the main carbon source was described earlier [30] and only slightly influences the amount of recombinant protein [39]. Due to the used optimized xylose-inducible promoter $\mathrm{P}_{x y l A}$ the D1.3 scFv concentration was found to be around tenfold enhanced compared to data published by David et al. [40].

\section{Bioprocess scale-down and scale-up}

Next, the culture volume was either reduced to $1250 \mu \mathrm{L}$ or increased to $2 \mathrm{~L}$ (Table 1). While miniaturization from $\mathrm{mL}$ to $\mu \mathrm{L}$ scale using microtiter plates is advantageous 


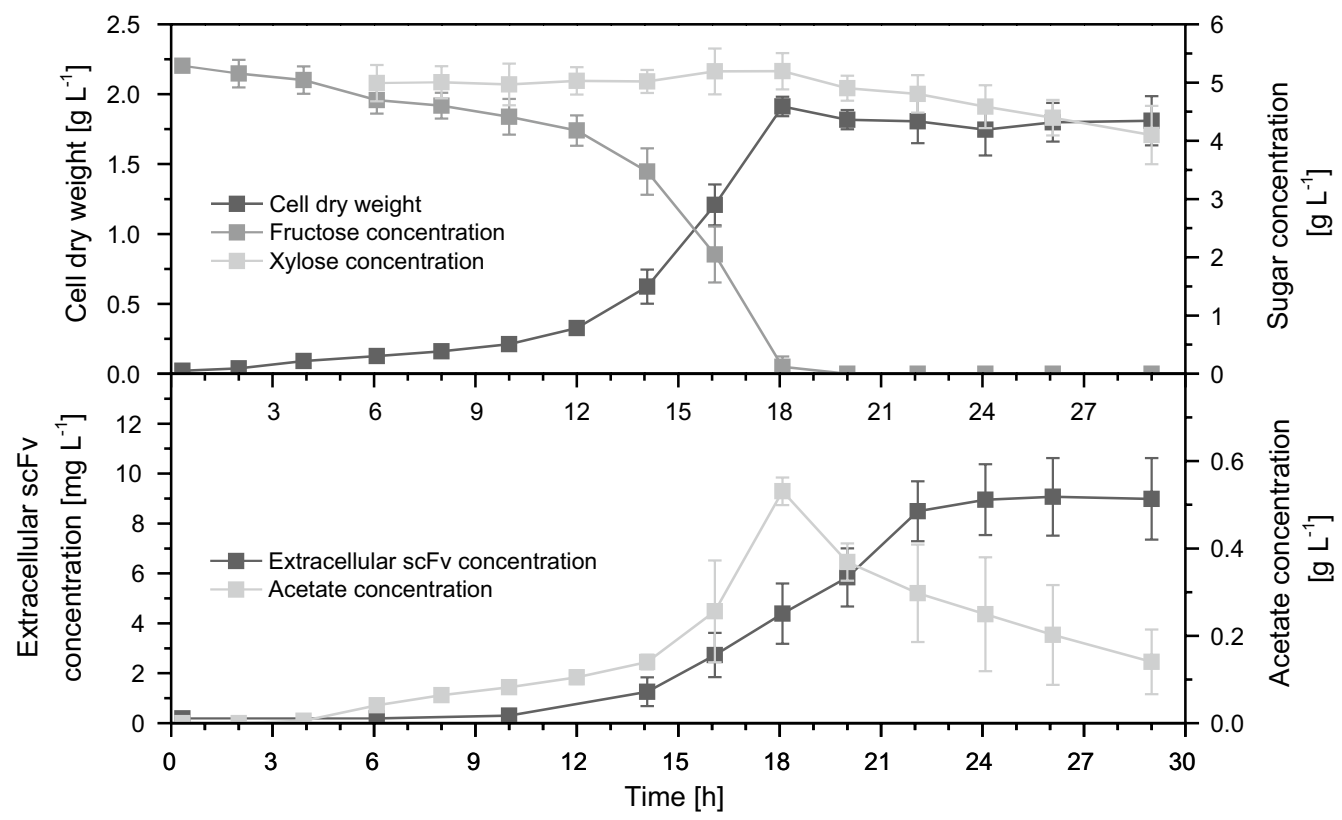

Fig. 2 Cultivation profile of recombinant B. megaterium MS941 secreting D1.3 scFv in shake flasks. B. megaterium MS941 was transformed with plasmid pRBBm 117 ( Popt $_{x y / A}$-sp lipA $\left.-d 1.3 s c F v-h i s_{6}\right)$. Cultivation took place in baffled shake flasks (150 mL culture volume) under aerobic conditions at $37^{\circ} \mathrm{C}$. Cultures were inoculated with cell concentrations (cell dry weight) of $0.0223 \mathrm{~g} \mathrm{~L}^{-1}$ in minimal medium containing $10 \mathrm{mg} \mathrm{L}^{-1}$ of tetracycline. Recombinant D1.3 scFv secretion was induced by the addition of $5 \mathrm{~g} \mathrm{~L}^{-1}$ of xylose at cell concentrations of around $0.07 \mathrm{~g} \mathrm{~L}^{-1}$. Samples were taken at given time points to analyze cell dry weight $\left[\mathrm{g} \mathrm{L}^{-1}\right]$, extracellular concentrations of D1.3 scFv [mg L $\left.{ }^{-1}\right]$ using ELISA and of fructose, xylose and acetate using HPLC

for processing a large number of parallel experiments, lab-scale stirred tank bioreactors provide more opportunities for online measuring and controlling various cultivation parameters. One of the important parameters in this study was the oxygen supply. For shake flasks and microtiter plates, oxygen input was realized via orbital shaking movements. As the ratio of gas-liquid exchange area to liquid volume strongly increased in microtiter plates compared to that provided in the shake flasks [41], a higher oxygen transfer rate (OTR) with $k_{L} a$ values of $150-200 \mathrm{~h}^{-1}$ was obtained. For stirred tank bioreactors, oxygen input was ensured via direct air inflow and agitation and $k_{L} a$ values of $75-85 \mathrm{~h}^{-1}$ were measured. However, addition of $15 \mathrm{mg} \mathrm{L}^{-1}$ anti-foaming agent after around $9 \mathrm{~h}$ of cultivation was necessary in bioreactor cultivations. Anti-foaming agents usually decreases oxygen transfer due to coalescence of bubbles and by retarding surface flow at the gas liquid interface [42, 43]. The DO dropped to nearly $0 \%$ and a sudden rise of dissolved oxygen (DO) to $80 \%$ marked the transition to the stationary phase in the bioreactor cultivations (Fig. 3). In the microtiter plates, the DO declined to only $40 \%$ due to better oxygen transfer. Lower oxygen tension slowed the energy generation of the respiratory chain and the present fructose concentration caused overflow metabolism
[44], indicated by the secretion of acetate during growth (Fig. 2 and Additional file 1: Figure S1) which has been described previously [40, 45]. In this study, maximal acetate concentrations of $0.45-0.55 \mathrm{~g} \mathrm{~L}^{-1}$ were attained in shake flask and bioreactor cultivations, but only $0.25 \mathrm{~g} \mathrm{~L}^{-1}$ in microtiter plate experiments. Acetate as non-preferential substrate was re-utilized after fructose depletion in shake flasks and microtiter plates. Finally, the oxygen availability also influences the amount of recombinant D1.3 scFv produced (Fig. 3). While in the bioreactor the production profile of $\mathrm{D} 1.3 \mathrm{scFv}$ was found to be very similar to that in shake flasks with maximal concentrations of $8 \mathrm{mg} \mathrm{L}^{-1}$ after $22-23 \mathrm{~h}$ of cultivation, in microtiter plates higher concentrations of up to $15 \mathrm{mg} \mathrm{L}^{-1}$ were reached already after $17-18 \mathrm{~h}$. As the product was secreted in both growth and stationary phase, secretion was assumed to be mixed-growth-associated or slightly growth-independent with $\alpha=0.28 \mathrm{mg}_{\text {scFv }} \mathrm{g}_{\text {cells }}^{-1}$ and $\beta=0.79 \mathrm{mg}_{\text {scFv }} \mathrm{g}_{\text {cells }}^{-1} \mathrm{~h}^{-1}$ for microtiter plate cultivations and $\alpha=0 \mathrm{mg}_{\text {scFv }} \mathrm{g}_{\text {cells }}^{-1}$ and $\beta=0.31 \mathrm{mg}_{\text {scFv }} \mathrm{g}_{\text {cells }}^{-1} \mathrm{~h}^{-1}$ for bioreactor experiments (Additional file 1: Table S1). The amount of active antibody fragment remained constant also in late stationary phase or even further increased during microtiter plate cultivation (Figs. 2,3) indicating a stable product form. 




Fig. 3 Cultivation profile of recombinant B. megaterium MS941 secreting D1.3 scFv in microtiter plates and bioreactors. B. megaterium MS941 was


bioreactors ( $2 \mathrm{~L}$ culture volume) under aerobic conditions at $37^{\circ} \mathrm{C}$. All cultivation systems were inoculated with cell concentrations (cell dry weight) of $0.0223 \mathrm{~g} \mathrm{~L}^{-1}$ in minimal medium containing $10 \mathrm{mg} \mathrm{L}^{-1}$ of tetracycline. Recombinant D1.3 scFv secretion was induced by the addition of $5 \mathrm{~g} \mathrm{~L}^{-1}$ of xylose at cell concentrations of around $0.07 \mathrm{~g} \mathrm{~L}^{-1}$. Samples were taken at given time points to analyze cell dry weight [ $\mathrm{L} \mathrm{L}^{-1}$ ] and extracellular concentration of D1.3 scFv [mg L ${ }^{-1}$ ] using ELISA. Dissolved oxygen was measured online. Further analyses are shown in Additional file 1: Figure S1

Production of recombinant D1.3 scFv using B. licheniformis Xylose-inducible gene expression can also be found in $B$. licheniformis [46] indicating its ability to take up xylose present in the medium. Hence, the plasmid pRBBm117 constructed for recombinant xylose-dependent D1.3 $\mathrm{scFv}$ secretion in $B$. megaterium was introduced into B. licheniformis strain MW3 [47]. Strain MW3 is a restriction-negative mutant of the type strain DSM13 in which two type I restriction modification systems were destructed enabling a better transformation and higher stability of foreign DNA compared to the wild type [47].

The growth behavior of recombinant $B$. licheniformis MW3 (Fig. 4) was similar for all three cultivation systems with maximal specific growth rates of $0.34-0.42 \mathrm{~h}^{-1}$. In contrast to recombinant $B$. megaterium, growth was not notably reduced after addition of the inducer xylose 4-5 $\mathrm{h}$ after inoculation. In all three systems, fructose was consumed after $12-14 \mathrm{~h}$ and stationary phase was reached with about $1.5-2.0 \mathrm{~g} \mathrm{~L}^{-1}$ of cell dry weight. Less maximal biomass was formed compared to recombinant B. megaterium MS941.

In the bioreactor cultivation, DO decreased to nearly $0 \%$ at the end of the exponential growth phase
(Additional file 1: Figure S2) implying oxygen limitation although fructose was still available. In microtiter plates, better oxygen transfer resulted in a less strongly decrease of DO to $50-60 \%$. As for recombinant B. megaterium, this was accompanied by the secretion of the overflow metabolite acetate. Maximal acetate concentrations of $0.7 \mathrm{~g} \mathrm{~L}^{-1}$ were detected in bioreactors, but only $0.4 \mathrm{~g} \mathrm{~L}^{-1}$ in shake flaks and microtiter plates when the culture reached the stationary phase. Re-utilization of the secreted acetate as well as partly metabolization of xylose explains the slight biomass increase after fructose depletion in bioreactors and microtiter plates. Secretion and re-utilization of acetate [48] and the utilization of xylose as carbon source [49] were described previously.

Although growth was not affected by the addition of the inducer, slightly higher amounts of recombinant functional D1.3 $\mathrm{scFv}$ were secreted by recombinant $B$. licheniformis compared to $B$. megaterium. Highest product amounts were again reached in microtiter plates $\left(17 \mathrm{mg} \mathrm{L}{ }^{-1}\right.$ after $\left.18 \mathrm{~h}\right)$, followed by shake flasks (15 mg L $\mathrm{mg}^{-1}$ after $\left.15 \mathrm{~h}\right)$ and bioreactor cultivations $\left(13 \mathrm{mg} \mathrm{L}^{-1}\right.$ after $\left.18 \mathrm{~h}\right)$. Secretion seems to be non-growth-associated in microtiter plates 


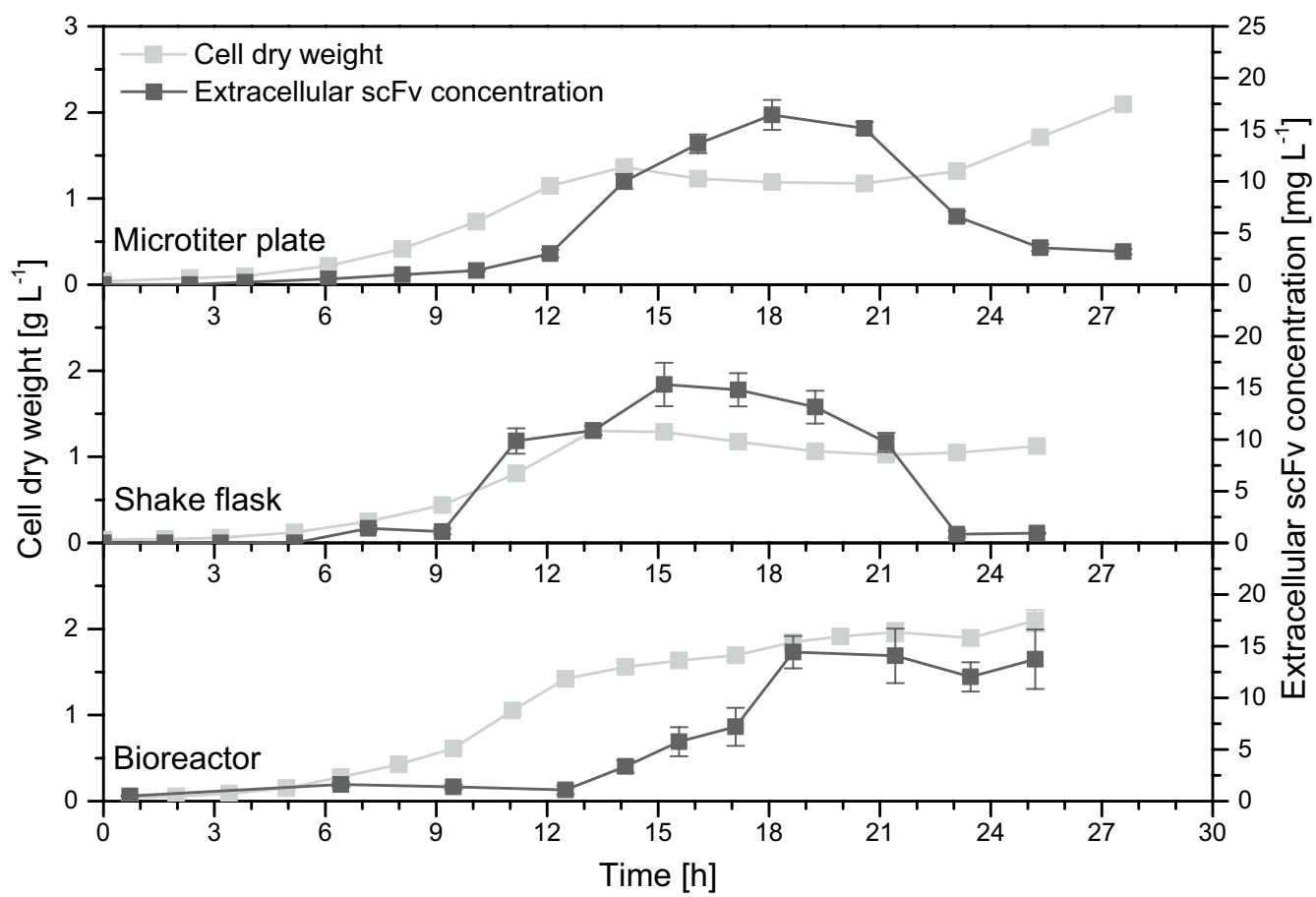

Fig. 4 Cultivation profile of recombinant B. licheniformis MW3 secreting D1.3 scFv. B. licheniformis MW3 was transformed with plasmid pRBBm117


stirred tank bioreactors ( $2 \mathrm{~L}$ of culture volume) under aerobic conditions at $37^{\circ} \mathrm{C}$. All cultivation systems were inoculated with cell concentrations (cell dry weight) of $0.04 \mathrm{~g} \mathrm{~L}^{-1}$ in minimal medium containing $10 \mathrm{mg} \mathrm{L}^{-1}$ of tetracycline. Recombinant D1.3 scFv secretion was induced by the addition of $5 \mathrm{~g} \mathrm{~L}^{-1}$ of xylose at cell concentrations of around $0.12 \mathrm{~g} \mathrm{~L}^{-1}$. Samples were taken at given time points to analyze cell dry weight [g $\mathrm{L}^{-1}$ ] and extracellular concentrations of D1.3 scFv [mg L $\left.{ }^{-1}\right]$ using ELISA. Further analyses are shown in Additional file 1: Figure S2

$\left(\alpha=0 \mathrm{mg}_{\text {scFv }} \mathrm{g}_{\text {cells }}^{-1}\right.$ and $\left.\beta=1.19 \mathrm{mg}_{\mathrm{scFv}} \mathrm{g}_{\text {cells }}^{-1} \mathrm{~h}^{-1}\right)$ and bioreactors $\left(\alpha=0 \mathrm{mg}_{\mathrm{scFv}} \mathrm{g}_{\text {cells }}^{-1}\right.$ and $\left.\beta=0.51 \mathrm{mg}_{\mathrm{scFv}} \mathrm{g}_{\text {cells }}^{-1} \mathrm{~h}^{-1}\right)$ as occurring mainly in the stationary phase (Additional file 1: Table S1). For shake flask cultivation, mixed-growth-associated secretion was observed with $\alpha=3.286 \mathrm{mg}_{\text {scFv }} \mathrm{g}_{\text {cells }}^{-1}$ and $\beta=1.286 \mathrm{mg}_{\text {scFv }} \mathrm{g}_{\text {cells }}^{-1} \mathrm{~h}^{-1}$ (Additional file 1: Table S1). For cultivations in microtiter plates and shake flasks, extracellular scFv concentration decreases during stationary phase. Since B. licheniformis DSM13, the wild type strain of the here-used derivate MW3, is known to produce various extracellular proteases including well-studied Subtilisin Carlsberg [50], degradation of scFv by these enzymes is assumed.

\section{Influence of genome-encoded proteases on the amount of secreted D1.3 scFv in recombinant $B$. subtilis}

Next, three different B. subtilis strains, 168 [51], DB431 [52] and WB800N [53, 54], were individually transformed with the production plasmid pRBBm117. The three $B$. subtilis strains differ in their gene sets for intra- and extracellular proteases what should strongly influence the stability of recombinant D1.3 scFv inside and outside of the cell. Compared to the wild type strain B. subtilis
168 , B. subtilis strain DB431 is deficient in four extracellular [subtilisin E (AprE), neural metalloprotease (Npr), minor extracellular protease (Epr), extracellular metalloprotease (Mpr)] and two intracellular proteases [the major intracellular serine protease (IspA) and bacillopeptidase F (Bpr)] $[52,55]$. B. subtilis strain WB800N is also a derivative of strain 168 and lacks six extracellular proteases namely subtilisin E (AprE), neural protease B (NprB), bacillolysin (NprE), two minor extracellular proteases (Epr and $\mathrm{Vpr}$ ) and metalloprotease (Mpr) as well as a cell wall-associated protease (WprA) and intracellular bacillopeptidase F (Bpr) [53-55].

Since B. subtilis was described to ineffectively utilize xylose as carbon source due to a missing specific transport system [56], the suitability of the here used and optimized xylose-inducible plasmid system had to be tested for the used strains. For this purpose, extracellular precipitated proteins were compared after xylose-induced and non-induced cultivations after $13-15 \mathrm{~h}$ in shake flasks via SDS-PAGE. In the medium of all three B. subtilis strains the antibody fragment D1.3 scFv, a monomeric protein with a molecular weight of approximately $27 \mathrm{kDa}$, was clearly observed for induced, but only marginally 
for non-induced cultivations (Fig. 5a). This indicated the enhanced production and secretion of D1.3 $\mathrm{scFv}$ in the presence of xylose and confirmed the correct function of the here used xylose-inducible promoter system. At the same time, the used plasmid system revealed a high segregational stability in the here tested $B$. subtilis strains. The application of the xylose-inducible promoter in B. subtilis was described previously but was only tested as genomically integrated system due to plasmid instabilities [57]. In addition, the amount of secreted D1.3 scFv positively correlated with the number of eliminated proteases. $B$. subtilis WB800N showed the highest and B. subtilis 168 the lowest concentration of D1.3 scFv (Fig. 5b). Although B. megaterium strain MS941 showed a very low protease activity [36], there was only very low extracellular overall protein and corresponding very low amount
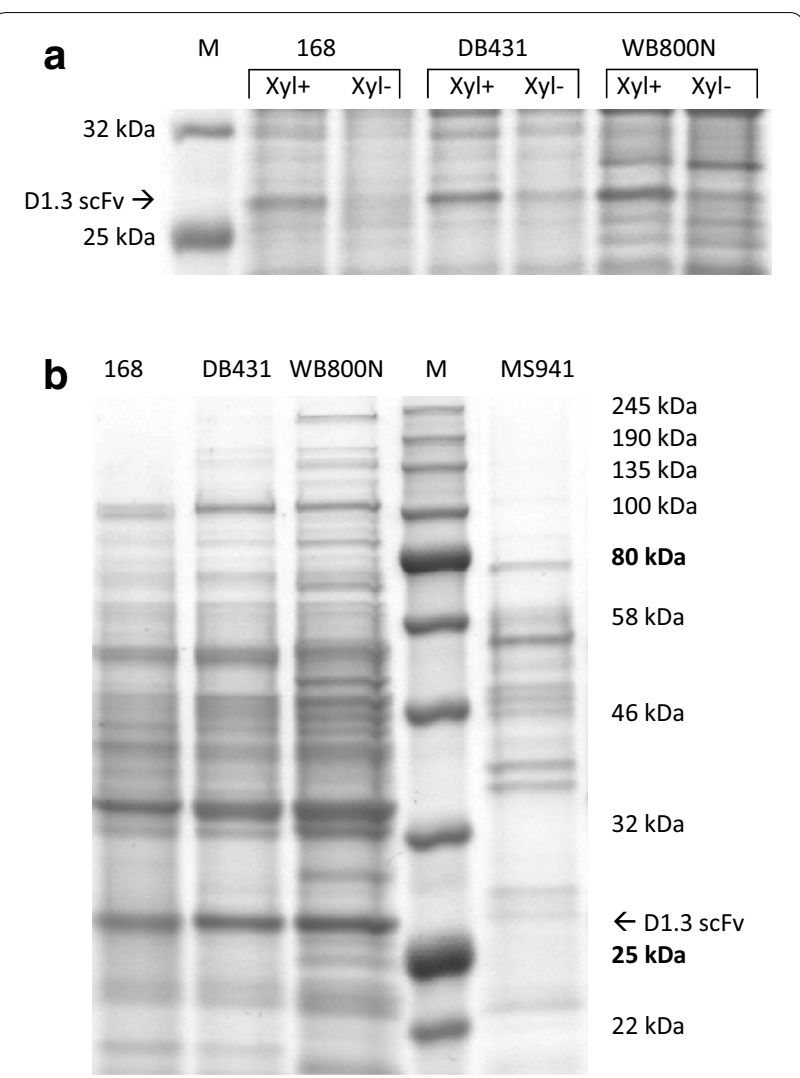

Fig. 5 Secretion of D1.3 scFv and other extracellular proteins by recombinant Bacillus strains. Extracellular proteins of $188 \mu \mathrm{L}$ culture supernatant from shake flasks were precipitated and analyzed by SDS-PAGE. a Extracellular proteins of B. subtilis strains 168, DB431 and WB800N were analyzed by SDS-PAGE after $13-15 \mathrm{~h}$ of cultivation. Xylose-induced $(X y \mid+)$ and non-induced $(X y l-)$ cultures were compared with a protein standard (marker $M)$. Only the proteins with a size between 25 and $32 \mathrm{kDa}$ are shown. $\mathbf{b}$ Extracellular proteins of induced B. megaterium MS941 (22 h) and B. subtilis 168, DB431 and WB800N (13-15 h) were precipitated and analyzed by SDS-PAGE compared with a protein standard (marker $M$ ) of extracellular D1.3 scFv visible compared to WB800N (Fig. 5b).

\section{Production and secretion of recombinant penicillin G acylase in different Bacillus strains}

To verify obtained results for the recombinant production of D1.3 scFv similar experiments were performed for the recombinant production of the exo-enzyme penicillin $\mathrm{G}$ acylase (Pac) using B. megaterium MS941, B. subtilis 168 and $B$. subtilis WB800N. Pac consists of a small $\alpha$ subunit $(27 \mathrm{kDa})$ and a large $\beta$ subunit $(59 \mathrm{kDa})$ which are autocatalytically processed from a cytoplasmic polypeptide precursor and folded outside the cell after secretion [30,31]. For recombinant production of Pac in different Bacillus strains, the expression plasmid pALBm1 was constructed, which encodes the Pac protein from $B$. megaterium ATCC14945 with its original signal peptide. Transcription of the corresponding gene is controlled by the optimized xylose-inducible promoter system. All other structures of pALBm 1 are identical to these of the plasmid pRBBm 117 used for antibody fragment production. Cultivations of transformed B. megaterium MS941 as well as B. subtilis 168 and WB800N were performed in shake flasks with $150 \mathrm{~mL}$ of LB medium at $37^{\circ} \mathrm{C}$.

Growth was similar for all investigated strains. All strains reached the stationary phase after $21 \mathrm{~h}$ with cell dry weights of about $2 \mathrm{~g} \mathrm{~L}^{-1}$ (Fig. 6). Production of active recombinant protein was demonstrated for all tested strains. Maximal extracellular Pac activities of $0.4 \mathrm{U} \mathrm{mL}^{-1}(24-32 \mathrm{~h}), 0.3 \mathrm{U} \mathrm{mL}^{-1}(18 \mathrm{~h})$ and $0.65 \mathrm{U} \mathrm{mL}^{-1}(24-32 \mathrm{~h})$ were detected for B. megaterium MS941, B. subtilis 168 and B. subtilis WB800N, respectively. Maximal Pac activities were observed after longer cultivation times compared to those required for maximal concentrations of D1.3 scFv. Here again B. subtilis 168 reached maximal product amount earlier compared to B. megaterium MS941 and B. subtilis WB800N (Fig. 6). The lowest Pac activities of $0.3 \mathrm{U} \mathrm{mL}^{-1}$ were observed with $B$. subtilis 168, which were even lower than with B. megaterium MS941 (0.4 $\left.\mathrm{U} \mathrm{mL}^{-1}\right)$, probably showing the influence of highly active proteases, while the lack of eight proteases characterizing B. subtilis WB800N doubled the maximal activity to $0.65 \mathrm{U} \mathrm{mL}^{-1}$. The observed production and secretion behavior for Pac was similar for all tested strains compared to the antibody fragment production and secretion.

\section{Time-resolved comparison of recombinant D1.3 scFv secretion in different $B$. subtilis strains}

Next, B. subtilis strains 168, DB431 and WB800N all transformed with pRBBm 117 were individually cultivated in microtiter plates, shake flasks, and bioreactors (Table 1) investigating time-resolved growth behavior and secretion 


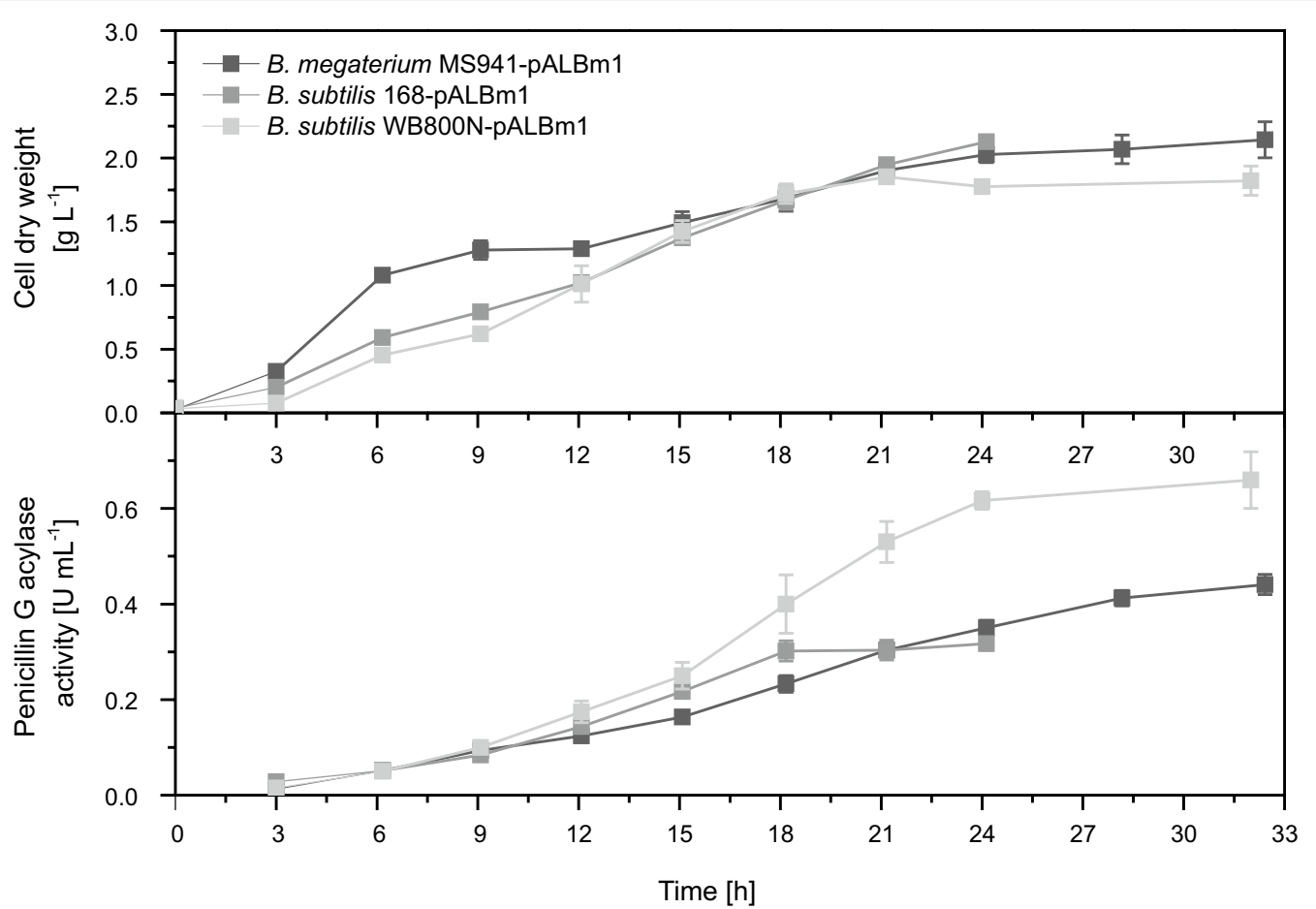

Fig. 6 Time-dependency of cell dry weight and penicillin G acylase activity for cultivation of recombinant Bacillus strains. Cultivation took place in baffled shake flasks ( $150 \mathrm{~mL}$ culture volume) under aerobic conditions at $37^{\circ} \mathrm{C}$ in LB medium containing $10 \mathrm{mg} \mathrm{L}^{-1}$ of tetracycline. Samples were taken at given time points to analyze cell dry weight $\left[\mathrm{g} \mathrm{L}^{-1}\right]$ and activity of penicillin $\mathrm{G}$ acylase $\left[\mathrm{U} \mathrm{mL}^{-1}\right]$ via enzymatic assay

of D1.3 scFv. Recombinant B. subtilis 168 and B. subtilis DB431 grew faster with maximal specific growth rates of $0.42-0.53 \mathrm{~h}^{-1}$ in all three cultivation systems compared to recombinant $B$. megaterium and B. licheniformis (Additional file 1: Figure S3). Recombinant D1.3 scFv production and secretion was induced after $2.5-3.5 \mathrm{~h}$, resulting in decreased specific growth rates of $0.16-0.27 \mathrm{~h}^{-1}$ until reaching $0.34-0.49 \mathrm{~h}^{-1}$ again about $4-6 \mathrm{~h}$ after induction. Stationary phase was already reached after $10-12 \mathrm{~h}$ with maximal cell dry weights of $1.5-2.0 \mathrm{~g} \mathrm{~L}^{-1}$. In contrast, growth of recombinant $B$. subtilis strain WB800N was slower $\left(0.36-0.41 \mathrm{~h}^{-1}\right)$. Also, induction of recombinant scFv secretion after 3.0-3.5 h of growth resulted in less decreased growth rate $\left(0.22-0.29 \mathrm{~h}^{-1}\right)$. Stationary phase was reached after $12-14 \mathrm{~h}$, but lower maximal cell dry weights of $1.0-1.3 \mathrm{~g} \mathrm{~L}^{-1}$ were detected compared to the other two B. subtilis strains. During stationary phase, xylose was partly metabolized $\left(1.0-2.5 \mathrm{~g} \mathrm{~L}^{-1}\right)$ by all three B. subtilis strains after depletion of fructose (Additional file 1: Figures S4-S6), again indicating an efficient uptake of the sugar.

Cultivating B. subtilis strains in bioreactor, significant foam formation was fought by addition of overall $30 \mathrm{mg} \mathrm{L}^{-1}$ (168), $50 \mathrm{mg} \mathrm{L}^{-1}$ (DB431) and $100 \mathrm{mg} \mathrm{L}^{-1}$ (WB800N) of anti-foaming agent. The observed amount of foam can be explained by the high amount of extracellular proteins known to encourage foam formation [58] (Fig. 5b). The DO dropped to 0\% $3 \mathrm{~h} \mathrm{(168)} \mathrm{and} 2 \mathrm{~h}$ (DB431) prior transition to stationary phase (Additional file 1: Figures S4, S5). Due to slower growth for WB800N, the DO of this strain only dropped down to $20 \%$ about $2 \mathrm{~h}$ before transition to stationary phase (Additional file 1: Figure S6) since a lower OTR into the cells was needed. The observed oxygen limitation in bioreactor cultivations resulted in the secretion of the fermentation product acetate in high amounts of $0.6 \mathrm{~g} \mathrm{~L}^{-1}$ (168), $0.7 \mathrm{~g} \mathrm{~L}^{-1}$ (DB431) and $0.9 \mathrm{~g} \mathrm{~L}^{-1}$ (WB800N) (Additional file1: Figures S4-S6). In contrast to that, culture volume reduction realized higher OTR and minimal $D O$ values of $20-50 \%$ (168), 40\% (DB431) and 80\% (WB800N) in microtiter plates resulting in lower amounts of secreted acetate [0.1 $\mathrm{g} \mathrm{L}^{-1}$ (168), 0.3-0.4 $\mathrm{g} \mathrm{L}^{-1}$ (DB431), $0.7 \mathrm{~g} \mathrm{~L}^{-1}$ (WB800N)] compared to bioreactor cultivations. For all B. subtilis strains and cultivation systems, maximal acetate concentrations occurred simultaneously at transition to stationary phase. Finally, strains 168 and DB431 re-utilized secreted acetate completely in the stationary phase, resulting in another decline of DO in the bioreactors, but due to low concentrations of acetate this was not the case in microtiter plates (Additional file 1: Figures 
S4, S5). Strain WB800N only partly metabolized the acetate in the growth medium (Additional file 1: Figure S6). Secretion and re-utilization of acetate was described previously for another B. subtilis strain [59].

Biologically active D1.3 scFv was secreted with all three recombinant $B$. subtilis strains in all three cultivation systems (Figs. 7, 8). Secretion was observed to be strongly (168) or mainly (DB431 and WB800N) growth-associated, since maximal concentrations were observed during or shortly after transition into stationary phase, respectively (Additional file 1: Table S1). Growth-associated secretion of a scFv with $B$. subtilis was described earlier with much lower product concentration although using a protease deficient strain [60]. In this study, maximal formed and secreted D1.3 $\mathrm{scFv}$ concentrations significantly differed depending on the used B. subtilis strain and the employed cultivation system. Maximal D1.3 $\mathrm{scFv}$ amounts in shake flasks were $30 \mathrm{mg} \mathrm{L}^{-1}$ (168, after $\left.12-13 \mathrm{~h}\right), 50 \mathrm{mg} \mathrm{L}^{-1}$ (DB431, after $14 \mathrm{~h}$ ) and $120 \mathrm{mg} \mathrm{L}^{-1}$ (WB800N, after 16-18 h), respectively, while for B. subtilis DB431 and WB800N, slightly higher concentrations were observed in microtiter plates $\left(60\right.$ and $130 \mathrm{mg} \mathrm{L}^{-1}$ ) due to better OTRs. For bioreactors, lower maximal D1.3 scFv concentration of $20 \mathrm{mg} \mathrm{L}^{-1}$ (168), $30 \mathrm{mg} \mathrm{L}^{-1}$ (DB431) and $70 \mathrm{mg} \mathrm{L}^{-1}$ (WB800N) were obtained, which might be due to the limited supply of oxygen or a negative effect of the added anti-foaming agent on product formation or secretion [61]. Compared to B. megaterium MS941 and B. licheniformis MW3, higher D1.3 scFv concentrations were achieved in less cultivation time with all three $B$. subtilis strains.

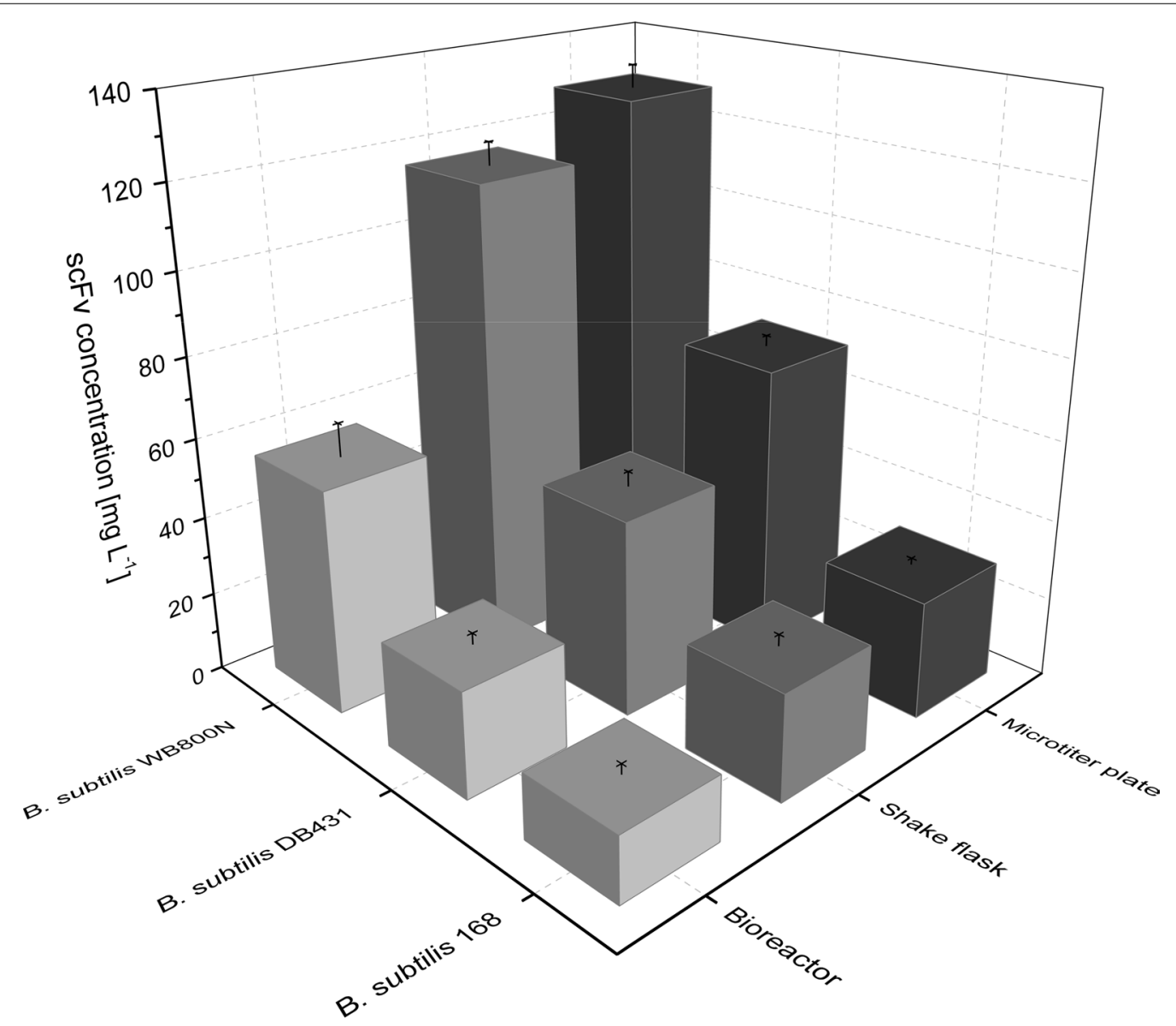

Fig. 7 Maximal extracellular D1.3 scFv concentrations for recombinant B. subtilis 168, DB431 and WB800N. B. subtilis strains were transformed with

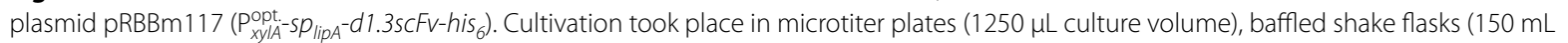
culture volume) and stirred tank bioreactors ( $2 \mathrm{~L}$ culture volume) under aerobic conditions at $37^{\circ} \mathrm{C}$. All cultivation systems were inoculated with cell concentrations (cell dry weight) of $0.0337 \mathrm{~g} \mathrm{~L}^{-1}$ in minimal medium containing $10 \mathrm{mg} \mathrm{L}^{-1}$ of tetracycline. Recombinant D1.3 scFv secretion was induced by the addition of $5 \mathrm{~g} \mathrm{~L}^{-1}$ of xylose at cell concentrations of around $0.10 \mathrm{~g} \mathrm{~L}^{-1}$. Extracellular concentration of D1.3 scFv [mg L $\mathrm{m}^{-1}$ ] for $B$. subtilis 168, DB431 and WB800N was analyzed using ELISA. Further analyses are shown in Additional file 1: Figures S3-S6 




Fig. 8 Time-dependent extracellular concentration of D1.3 scFv for the recombinant B. subtilis 168, DB431 and WB800N. Cultivation took place in microtiter plates $(1250 \mu \mathrm{L}$ culture volume), baffled shake flasks $(150 \mathrm{~mL}$ of culture volume) and bioreactors ( $2 \mathrm{~L}$ culture volume) under aerobic conditions at $37^{\circ} \mathrm{C}$. All cultivation systems were inoculated with cell concentrations (cell dry weight) of $0.0337 \mathrm{~g} \mathrm{~L}^{-1}$ in minimal medium containing $10 \mathrm{mg} \mathrm{L}^{-1}$ of tetracycline. Recombinant D1.3 scFv secretion was induced by the addition of $5 \mathrm{~g} \mathrm{~L}^{-1}$ of xylose at cell concentrations of around $0.07 \mathrm{~g} \mathrm{~L}^{-1}$. Samples were taken at given time points to analyze extracellular concentration of D1.3 scFv [mg L $\mathrm{L}^{-1}$ for B. subtilis 168 , DB431 and WB800N using ELISA

Bacillus subtilis 168 did not only secrete the smallest amount of D1.3 scFv among the examined B. subtilis strains but its extracellular scFv concentration also strongly decreased during stationary phase for all cultivation systems. Especially in stirred tank bioreactors, $\mathrm{scFv}$ concentration dropped dramatically fast in stationary phase of cultivation, resulting in a quite narrow and small concentration profile. Here, degradation by proteases was strongly assumed, since B. subtilis 168 is known to produce and secrete high amounts of different proteases, especially at the end of growth phase [62]. Apparently, the absence of six proteases in B. subtilis DB431 resulted in higher and more constant $\mathrm{scFv}$ titer profiles, although degradation of $\mathrm{scFv}$ during stationary phase still occurred (Fig. 8). Finally, B. subtilis WB800N, lacking eight proteases, secreted the highest $\mathrm{scFv}$ amounts for all three cultivation systems and no significant degradation of $\mathrm{scFv}$ occurred in any cultivation system during stationary phase clearly indicating the positive influence of proteases deficiency on the recombinant protein production and secretion in this $B$. subtilis strain.

\section{Space-time-yield (STY) of D1.3 scFv secretion in Bacillus}

For overall balancing and evaluation of the production and secretion of D1.3 scFv, the space-time-yield (STY) was calculated as the proportion of $\mathrm{scFv}$ concentration and corresponding cultivation time (Fig. 9). For recombinant $B$. megaterium, STY of about $0.35 \mathrm{mg} \mathrm{L}^{-1} \mathrm{~h}^{-1}$ for shake flasks and bioreactors and of $0.62 \mathrm{mg} \mathrm{L}^{-1} \mathrm{~h}^{-1}$ for microtiter plates were attained. With recombinant $B$. licheniformis, higher values of $1.01,0.77$ and $0.91 \mathrm{mg} \mathrm{L}^{-1} \mathrm{~h}^{-1}$ were observed. STY for recombinant $B$. subtilis were much higher. Here again, values increased from strain 168 over DB431 to WB800N. Cultivation in stirred tank bioreactors resulted in the lowest STY (1.8, 2.5 and $4.1 \mathrm{mg} \mathrm{L}^{-1} \mathrm{~h}^{-1}$ ) despite the short corresponding cultivation time. In microtiter plates, the highest values of $2.8,5.4$ and $8.0 \mathrm{mg} \mathrm{L}^{-1} \mathrm{~h}^{-1}$ were reached, even though these for shake flasks were only slightly lower (2.1, 3.6 and $7.0 \mathrm{mg} \mathrm{L}^{-1} \mathrm{~h}^{-1}$ ). The highest STY was reached with $B$. subtilis WB800N for all three cultivation systems. These STYs were about 15 times higher than that of the recombinant reference strain B. megaterium MS941. 


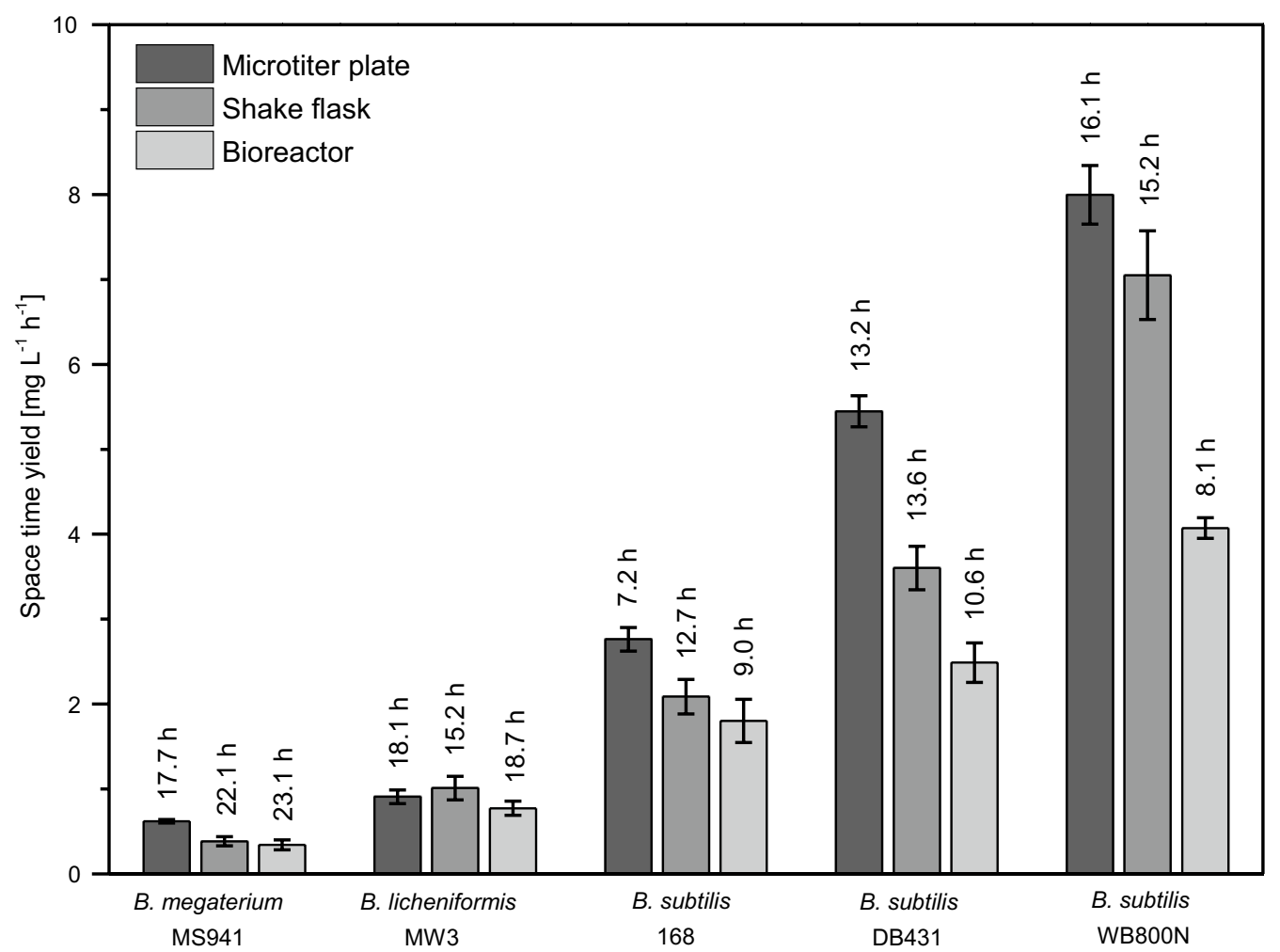

Fig. 9 Maximal space-time-yield of extracellular D1.3 scFv. Space-time-yields (STY; $\left[\mathrm{mg} \mathrm{L}^{-1} \mathrm{~h}^{-1}\right]$ ) were calculated as proportion of scFv concentration [mg L $\left.{ }^{-1}\right]$ and the corresponding cultivation time $[\mathrm{h}]$ for each examined Bacillus strain cultivated in microtiter plates, shake flasks and stirred tank bioreactors

\section{Discussion}

In this study, different strains of the genus Bacillus were shown to efficiently produce and secrete the recombinant antibody fragment D1.3 $\mathrm{scFv}$ as well as penicillin G acylase Pac in three different cultivation systems. For this, all strains were successfully transformed with the identical plasmid encoding D1.3 scFv and Pac, respectively, together with an optimized $B$. megaterium xylose-inducible promoter system and $B$. megaterium originated signal peptides [63]. This clearly shows the broad interspecies application of an expression plasmid in Bacillus, which was not investigated so far.

Production and secretion of scFvs and scFabs with $B$. megaterium were examined before using its native xylose-inducible promoter system. With this system, $390 \mu \mathrm{g} \mathrm{L}^{-1}$ of anti-CRP scFv [64], $410 \mu \mathrm{g} \mathrm{L}^{-1}$ of D1.3 scFv [33] and $3.5 \mu \mathrm{g} \mathrm{L}^{-1}$ of the more complex D1.3 scFab were produced and secreted in their active forms by $B$. megaterium strain MS941 [64] deficient in the main extracellular protease NprM lacking around $98 \%$ of the overall extracellular protease activity [36]. When compared to the production and secretion by a B. megaterium strain additionally deficient in xylose metabolization [30], D1.3 scFv secretion was enhanced to $700 \mu \mathrm{g} \mathrm{L}^{-1}$ in shake flasks and even $3 \mathrm{mg} \mathrm{L}^{-1}$ in $3 \mathrm{~L}$ bioreactors $[40,65]$. With E. coli, about $1-2 \mathrm{mg} \mathrm{L}^{-1}$ of D.13 scFv were recovered as soluble protein in the culture supernatant and as periplasmic fraction [66], showing the inefficient production in Gram-negative bacteria.

For $B$. licheniformis, no secretion of any $\mathrm{scFv}$ was described so far. For the here-used strain B. licheniformis MW3, scFv concentrations in the same range as for $B$. megaterium were achieved. Among the tested $B$. subtilis strains, highest amounts of active D1.3 scFv were secreted with the strain WB800N deficient in eight proteases. WB800N showed the highest product yield which was 8.7 -fold higher than the best $B$. megaterium MS941 cultivation and 4.3- and 2.2-fold higher than for $B$. subtilis strains 168 and DB431, respectively. Deficiencies of aprE, npr, epr, mpr, ispA and bpr of B. subtilis DB431 lead to doubling of scFv concentration (up to $60 \mathrm{mg} \mathrm{L}^{-1}$ ) compared to B. subtilis 168 (up to $30 \mathrm{mg} \mathrm{L}^{-1}$ ). Additional deficiency in $n p r B, v p r$ and wprA in B. subtilis WB800N resulted in another doubling of scFv concentration (up to $130 \mathrm{mg} \mathrm{L}^{-1}$ ). This is the highest level of a recombinant antibody fragment for a Gram-positive bacterium 
described so far. In the literature, B. subtilis strains, mostly mutants of strain 168 with deletions of one or more protease genes, show very low overall extracellular protease activity leading to improved yields of various products compared to the wild type strain [21]. Secretion of up to $15 \mathrm{mg} \mathrm{L}^{-1}$ with $B$. subtilis was described before $[53,60,67]$. The three-protease-deficient B. subtilis WB30 was reported to secrete $3.5 \mathrm{mg} \mathrm{L}^{-1}$ and the sixprotease-deficient WB600 $5 \mathrm{mg} \mathrm{L}^{-1}$ of an scFv against digoxin [60]. With coproduction of intracellular and extracytoplasmic molecular chaperones, $\mathrm{scFv}$ titers of $12 \mathrm{mg} \mathrm{L}^{-1}$ were observed [67]. With B. subtilis WB700N, a seven-extracellular-protease-deficient derivate, secretion of scFv against fibrin even failed [53]. However, the combination of enhanced coproduction of molecular chaperones and additional inactivation of the cell-wall-associated protease WprA in the strain WB800HM[pEPP] resulted in scFv titers of up to $15 \mathrm{mg} \mathrm{L}^{-1}$ [53]. In addition, correlation of increased stability of the produced $\mathrm{scFv}$ with less secreted proteases was observed comparing B. subtilis 168, WB30 and WB600 [60]. In accordance with that, in this study higher and more constant scFv titer profiles were observed for the protease-deficient B. subtilis strains DB431 and WB800N.

Apart from B. megaterium and B. subtilis, production of extracellular recombinant antibody fragments has been reported only for B. brevis and Lactobacillus spp. With B. brevis, secretion of about $100 \mathrm{mg} \mathrm{L}^{-1}$ of a Fab against human urokinase-type plasminogen activator was reported [68]. Lactobacillus spp. were used to secrete $6 \mu \mathrm{g} \mathrm{L}^{-1}$ of Guy's $13 \mathrm{scFv}$ against a streptococcal adhesion molecule [69], $410 \mu \mathrm{g} \mathrm{L}^{-1}$ of codon-optimized antiviral 3D8 scFv [70] and $1 \mathrm{mg} \mathrm{L}^{-1}$ of an of llama heavy-chain (VHH) antibody fragment against rotavirus [71].

In contrast to Bacillus-based production systems mammalian cell cultures produce antibodies at $\mathrm{g} \mathrm{L}^{-1}$ scale. However, much longer cultivation times of up to 3 weeks are needed. For example, using a human cell line $400-500 \mathrm{mg} \mathrm{L}^{-1}$ of IgG were produced within 10 days, corresponding to a STY of $1.66-2.08 \mathrm{mg} \mathrm{L}^{-1} \mathrm{~h}^{-1}$ [72]. IgG concentrations of $2.64 \mathrm{~g} \mathrm{~L}^{-1}$ (in 13 days) were realized with NSO cells, which corresponds to a STY of $8.46 \mathrm{mg} \mathrm{L}^{-1} \mathrm{~h}^{-1}$ [73]. For CHO cells up to $12.8 \mathrm{mg} \mathrm{L}^{-1} \mathrm{~h}^{-1}$ of IgG were described [74-76]. Since we observed maximal secretion with the tested Bacillus strains in only 9-21 h, the resulting STY of up to $8 \mathrm{mg} \mathrm{L}^{-1} \mathrm{~h}^{-1}$ are in the same order of magnitude as described for mammalian cells, showing the ability to compete with these cultivation systems for $\mathrm{scFv}$-secretion. However, cultivation costs are characteristically smaller for the bacterial production systems.
Recombinant production of penicillin $\mathrm{G}$ acylase Pac from B. megaterium ATCC14945 in other B. megaterium [30] and B. subtilis [77-79] strains was shown previously, using various cultivation systems and mainly complex media. Here, we used the production of this enzyme for the confirmation of the results obtained for $\mathrm{scFv}$-production and secretion. In agreement, the deficiency for eight proteases in B. subtilis WB800N led to a doubling of the maximal activity while the presence of all natural protease clearly reduced the amount of Pac in the medium, validating the assumptions made for D1.3 $\mathrm{scFv}$ production in protease-deficient $B$. subtilis strains. Overall, similar results were obtained in comparison to the recombinant secretion of D1.3 scFv, clearly confirming the general applicability of the introduced systems.

\section{Conclusions}

Different tested strains of the genus Bacillus provided high potential microbial production systems to synthesize and export challenging heterologous proteins like antibody fragments and high molecular weight proteins at high titers in different cultivation systems: a microtiter plate approach $(1250 \mu \mathrm{L}$ culture volume), uncontrolled shake flasks ( $150 \mathrm{~mL}$ culture volume) and a controlled laboratory-scale stirred tank bioreactor (2 L culture volume). The employed plasmid originally optimized for the recombinant protein production in $B$. megaterium can also efficiently be used for $B$. licheniformis and $B$. subtilis strains, which demonstrates its interspecies application. Kinetics of $\mathrm{D} 1.3 \mathrm{scFv}$ production were successfully described with the Luedeking-Piret model for all tested Bacillus strains and cultivation systems. Highest production and secretion of the antibody fragment was attained in microtiter plates and shake flask because of their better oxygen transfer compared to the stirred tank bioreactor approach. B. subtilis WB800N, deficient in eight proteases, secreted $130 \mathrm{mg} \mathrm{L}^{-1}$ (STY of $8 \mathrm{mg} \mathrm{L}^{-1} \mathrm{~h}^{-1}$ ) of the recombinant antibody fragment D1.3 scFv, which is the highest concentration and STY of a recombinant antibody fragment for a Grampositive bacterium described so far. Finally, interspecies application of the plasmid system were also shown for the secretion of a recombinant heterodimeric protein, the penicillin $\mathrm{G}$ acylase Pac.

\section{Methods}

\section{Strains and plasmids}

All strains and plasmids used in this study are listed in Table 2. For cloning procedures, E. coli strain DH10B acted as host (Life Technologies, Carlsbad, USA). B. megaterium strain MS941 is a derivate of the wild type strain DSM319 with a defined deletion in the gene encoding 
Table 2 Strains and plasmids used in this study

\begin{tabular}{|c|c|c|}
\hline Strain or plasmid & Description & Reference/source \\
\hline Escherichia coli DH10B & 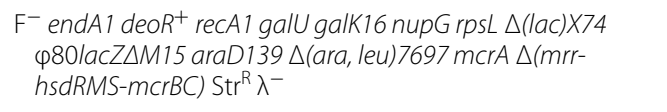 & Invitrogen, Carlsbad, USA \\
\hline Bacillus megaterium MS941 & Bacillus megaterium DSM319 $\triangle$ nprM & {$[36]$} \\
\hline Bacillus megaterium ATCC14945 & Produces penicillin G acylase & American Type Culture Collection; Manassas, Virginia; USA \\
\hline Bacillus licheniformis MW3 & Bacillus licheniformis DSM13 ( $\triangle h s d R 1, \Delta h s d R 2)$ & {$[47]$} \\
\hline Bacillus subtilis 168 & $\operatorname{trp} C 2$ & {$[51]$} \\
\hline Bacillus subtilis DB431 & trpC2 nprE18 aprE epr bpr mpr ispA & {$[52]$} \\
\hline Bacillus subtilis WB800N & $\begin{array}{l}\text { nprE aprE epr bpr mpr:::ble nprB::bsr } \triangle \text { vpr wprA::hyg cm::neo; } \\
\text { Neo }^{R}\end{array}$ & {$[53,54]$} \\
\hline pEJBmD1.3scFv & $\begin{array}{l}\text { Shuttle vector for the recombinant production and } \\
\text { secretion of } D 1.3 \mathrm{scFv} \text { in } B \text {. megaterium }\left(T c^{R}\right)\end{array}$ & [33] \\
\hline p3STOP1623hp & 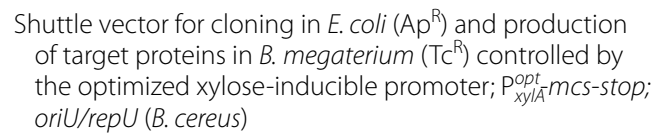 & [32] \\
\hline pRBBm 117 &  & This work \\
\hline pALBm1 & 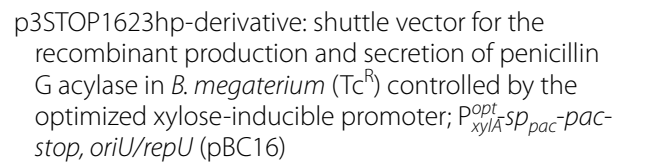 & This work \\
\hline
\end{tabular}

the major extracellular protease NprM [36, 80]. B licheniformis strain MW3, a derivate of the type strain DSM13, has defined deletions in genes encoding two type I restriction modification systems (HsdR1, HsdR2) to improve transformability and recombinant DNA stability [47]. $B$. subtilis 168 , the most widely biotechnologically used $B$. subtilis strain, is originated from B. subtilis Marburg via $\mathrm{X}$-ray-mutagenesis. It is tryptophan-requiring auxotroph [51]. B. subtilis strain DB431 is deficient in four extracellular and two intracellular proteases [52], while strain WB800N lacks six extracellular, one cell-wall-associated and one intracellular protease [53, 54]. For generation of the here used expression plasmid pRBBm117, the $D 1.3 s c F v$ gene fused to the coding sequences of the signal peptide of the B. megaterium lipase A [63] at its $5^{\prime}$-end, of a $\mathrm{His}_{6}$-tag at its $3^{\prime}$-end and of a terminator structure were liberated

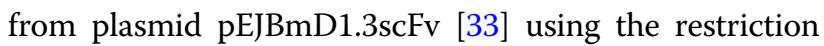
enzymes BsrGI and AgeI. The fragment was cloned into similarly cut p3STOP1623hp [32] resulting in pRBBm117. For generation of expression plasmid pALBm1, the pac gene encoding the penicillin $G$ acylase was amplified from genomic DNA of $B$. megaterium ATCC14945 using the primers pac_fw (5'-TACATATGTACAATGAAGACGAAGTGGCTAATATCA-3') and pac_rv (5'-TATCAGAGCTCATCAATAGTATAGGCTC-3'). The pac gene including the native signal peptide was cloned into the shuttle vector p3STOP1623hp [32] using SacI und BsrGI.

Isolation of genomic DNA from B. megaterium ATCC14945 For preparation of chromosomal DNA from $B$. megaterium ATCC14945, the JETquick Plasmid Miniprep Kit (Genomed, Löhne, Germany) was used according to the manufacturer's instructions with some modifications. Cells from a cryogenic glycerol stock were grown overnight at $37^{\circ} \mathrm{C}$ and $130 \mathrm{~min}^{-1}$ in $50 \mathrm{~mL}$ of LB medium in baffled flasks. Cells of $6 \mathrm{~mL}$ culture suspension were harvested and suspended in $250 \mu \mathrm{L}$ TE(H) buffer (150 mM Tris-HCl, 20 mM EDTA, pH 8) before $20 \mu \mathrm{L}$ of lysozyme solution ( $20 \mathrm{~g} \mathrm{~L}^{-1}$ lysozyme in $\mathrm{TE}(\mathrm{H})$ buffer) were added. Cells were incubated for $10 \mathrm{~min}$ at $37^{\circ} \mathrm{C}$ and $750 \mathrm{~min}^{-1}$ before adding the next buffer. Before elution of DNA, the column was washed with $500 \mathrm{~mL}$ of GX buffer and $500 \mu \mathrm{L}$ of $\mathrm{G} 4$ buffer.

\section{Transformation and strain maintenance}

Unless mentioned here, molecular biology methods used in this study were described previously [81]. Plasmid DNA for the transformation of B. megaterium MS941, $B$. licheniformis MW3 and B. subtilis 168 was prepared from recombinant $E$. coli while plasmid DNA for 
transformation of B. subtilis strains DB431 and WB800N was prepared from $B$. subtilis 168 already carrying the plasmid pRBBm117. All DNA preparations were done by using the QIAgen Spin Miniprep Kit (QIAgen, Hilden, Germany) according to the manufacturer's instructions with some modifications. For the preparation of plasmid DNA from Gram-positive B. subtilis, lysozyme ( $1 \mathrm{mg} \mathrm{mL}{ }^{-1}$ ) was added to the resuspension buffer for suspending cells of $50 \mathrm{~mL}$ culture $\left(\mathrm{OD}_{600}\right.$ of 1$)$. Cells were then incubated for $10 \mathrm{~min}$ at $37^{\circ} \mathrm{C}$ before adding the next buffer.

The protoplast transformation of $B$. megaterium was performed as outlined previously [82]. The protoplast transformation of $B$. licheniformis was performed according to Waschkau et al. [47]. All B. subtilis strains were transformed via induced natural competence. For this purpose, cells from a cryogenic glycerol stock were grown overnight at $37{ }^{\circ} \mathrm{C}$ and $230 \mathrm{~min}^{-1}$ in $10 \mathrm{~mL}$ competence medium in baffled flasks. The competence medium consists of $500 \mathrm{~mL} \mathrm{~L}^{-1} 2 \times \mathrm{SMM}$ (Spizizen minimal medium), $5 \mathrm{~g} \mathrm{~L}^{-1}$ glucose, $100 \mathrm{mg} \mathrm{L}^{-1}$ tryptophan, $1.48 \mathrm{~g} \mathrm{~L}^{-1} \mathrm{MgSO}_{4} \cdot 7 \mathrm{H}_{2} \mathrm{O}, 200 \mathrm{mg} \mathrm{L}^{-1}$ casamino acids and $1.1 \mathrm{mg} \mathrm{L}^{-1} \mathrm{Fe}^{-\mathrm{NH}_{4}}$-citrate. $2 \times \mathrm{SMM}$ consists of $4 \mathrm{~g} \mathrm{~L}^{-1}$ $\left(\mathrm{NH}_{4}\right)_{2} \mathrm{SO}_{4}, 28 \mathrm{~g} \mathrm{~L}^{-1} \mathrm{~K}_{2} \mathrm{HPO}_{4}, 12 \mathrm{~g} \mathrm{~L}^{-1} \mathrm{KH}_{2} \mathrm{PO}_{4}, 2 \mathrm{~g} \mathrm{~L}^{-1}$ Na-citrate $2 \mathrm{H}_{2} \mathrm{O}$ and $400 \mathrm{mg} \mathrm{L}{ }^{-1} \mathrm{MgSO}_{4} \cdot 7 \mathrm{H}_{2} \mathrm{O} .10 \mathrm{~mL}$ of fresh competence medium in a $100 \mathrm{~mL}$ baffled flask were inoculated with $600 \mu \mathrm{L}$ of the overnight culture. Cells were grown for $3 \mathrm{~h}$ at $37^{\circ} \mathrm{C}$ and $230 \mathrm{~min}^{-1}$ before $10 \mathrm{~mL}$ of pre-warmed starvation medium $\left(500 \mathrm{~mL} \mathrm{~L}^{-1} 2 \times \mathrm{SMM}\right.$, $5 \mathrm{~g} \mathrm{~L}^{-1}$ glucose, $1.48 \mathrm{~g} \mathrm{~L}^{-1} \mathrm{MgSO}_{4} \cdot 7 \mathrm{H}_{2} \mathrm{O}$ and $1.1 \mathrm{mg} \mathrm{L}^{-1}$ $\mathrm{Fe}-\mathrm{NH}_{4}$-citrate) were added. After another $2 \mathrm{~h}$ of incubation under same conditions, $400 \mu \mathrm{L}$ of the cell suspension were mixed with $1 \mu \mathrm{g}$ of corresponding plasmid DNA and incubated for $1 \mathrm{~h}$ at $1000 \mathrm{~min}^{-1}$ and $37^{\circ} \mathrm{C}$. Finally, $100 \mu \mathrm{L}$ were plated on $\mathrm{LB}$ agar with $10 \mathrm{mg} \mathrm{L}^{-1}$ of tetracycline and incubated overnight at $37^{\circ} \mathrm{C}$.

All strains were stored at $-80{ }^{\circ} \mathrm{C}$ in a $30 \%(\mathrm{v} / \mathrm{v})$ glycerol solution in cryogenic vials. For preparing cryogenic cultures, $50 \mathrm{~mL}$ of LB medium [81] with $10 \mathrm{mg} \mathrm{L}^{-1}$ of tetracycline for plasmid-carrying recombinant strains were inoculated with cell material from a LB agar plate and incubated at $37{ }^{\circ} \mathrm{C}$ and $230 \mathrm{~min}^{-1}$. During exponential phase $\left(\mathrm{OD}_{600}=1-2\right), 32.5 \mathrm{~mL}$ of the cell suspension were mixed with $17.5 \mathrm{~mL}$ of glycerol [86\% (v/v)], immediately frozen in $1 \mathrm{~mL}$ aliquots in liquid nitrogen and stored at $-80^{\circ} \mathrm{C}$

\section{Cultivation of recombinant strains}

The minimal medium used in this study for production of recombinant D1.3 scFv contained $5 \mathrm{~g} \mathrm{~L}^{-1}$ D-fructose, $25 \mathrm{~g} \mathrm{~L} \mathrm{~L}^{-1}\left(\mathrm{NH}_{4}\right)_{2} \mathrm{SO}_{4}, 300 \mathrm{mg} \mathrm{L}^{-1} \mathrm{MgSO}_{4} \cdot 7 \mathrm{H}_{2} \mathrm{O}$, $3.52 \mathrm{~g} \mathrm{~L}^{-1} \mathrm{KH}_{2} \mathrm{PO}_{4}, 5.3 \mathrm{~g} \mathrm{~L}^{-1} \mathrm{Na}_{2} \mathrm{HPO}_{4}, 10 \mathrm{mg} \mathrm{L}$ of tetracycline and $2 \mathrm{~mL} \mathrm{~L}^{-1}$ trace element solution.
For all B. subtilis strains, $16 \mathrm{mg} \mathrm{L}^{-1}$ tryptophan and $7.36 \mathrm{~g} \mathrm{~L}^{-1}$ glutamic acid were added. The trace element solution contained $424 \mathrm{mg} \mathrm{MnCl}_{2} \cdot 4 \mathrm{H}_{2} \mathrm{O}, 678.4 \mathrm{mg}$ $\mathrm{CaCl}_{2} \cdot 4 \mathrm{H}_{2} \mathrm{O}, 16.8 \mathrm{mg} \mathrm{FeSO}_{4} \cdot 4 \mathrm{H}_{2} \mathrm{O}, 1.4 \mathrm{mg} \mathrm{CoCl} 2,0.4 \mathrm{mg}$ $\mathrm{CuSO}_{4} \cdot 4 \mathrm{H}_{2} \mathrm{O}, 6.2 \mathrm{mg} \mathrm{H}_{3} \mathrm{BO}_{3}, 1.25 \mathrm{mg} \mathrm{ZnSO}_{4} \cdot 7 \mathrm{H}_{2} \mathrm{O}$ and $2.6 \mathrm{mg}\left(\mathrm{NH}_{4}\right)_{6} \mathrm{Mo}_{7} \mathrm{O}_{24} \cdot 4 \mathrm{H}_{2} \mathrm{O}$ per liter. For $100 \mathrm{~mL}$ of precultures, an adequate amount of cryogenic culture was used as inoculum $(100 \mu \mathrm{L}$ for B. megaterium, $250 \mu \mathrm{L}$ for B. licheniformis, $50 \mu \mathrm{L}$ for $B$. subtilis 168 and DB431 and $150 \mu \mathrm{L}$ for $B$. subtilis WB800N). These pre-cultures were grown in $500 \mathrm{~mL}$ baffled flasks at $37^{\circ} \mathrm{C}$ and $130 \mathrm{~min}^{-1}$ for $18 \mathrm{~h}$. Main cultures were inoculated with a pre-culture volume adjusting to an $\mathrm{OD}_{600}$ of 0.1 . Inoculation culture was centrifuged $(1500 \times g, 5 \mathrm{~min}$, room temperature) before suspended in fresh minimal medium. Expression of the $D 1.3 s c F v$ was induced by addition of $5 \mathrm{~g} \mathrm{~L}^{-1}$ D-xylose at an $\mathrm{OD}_{600}$ of 0.3-0.4.

For shake flasks cultivation for production of recombinant D1.3 scFv, $150 \mathrm{~mL}$ of minimal medium were incubated in $500 \mathrm{~mL}$ baffled flasks ( 3 baffles) at $37{ }^{\circ} \mathrm{C}$ and $130 \mathrm{~min}^{-1}$ (50 mm orbital shaking diameter). Shake flask cultivations were carried out in triplicate. For bioreactor cultivation, $3 \mathrm{~L}$ bioreactors (Applikon, Schiedam, The Netherlands) with two six-bladed Rushton turbine impellers were used. Cultivation was performed with $2 \mathrm{~L}$ of minimal medium. Temperature $\left(37 \pm 0.1{ }^{\circ} \mathrm{C}\right)$, aeration rate $\left(3.0 \mathrm{~L} \mathrm{~min}{ }^{-1}, 1.5 \mathrm{vvm}\right)$, agitation speed $\left(500 \mathrm{~min}^{-1}\right)$ and $\mathrm{pH}$ value $(\mathrm{pH} 6.5 \pm 0.1$, adjusted with $2 \mathrm{M} \mathrm{HCl}$ and $2 \mathrm{M} \mathrm{NaOH}$ ) were automatically kept constant. Dissolved oxygen (DO) was measured online. Bioreactor cultivations were carried out in duplicate (strains MS941, MW3, 168) and triplicate (strains DB431, WB800N), respectively. To prevent foam formation, anti-foaming agent (Ucolub ${ }^{\circledR}$, FRAGOL GmbH \& Co. KG, Mühlheim/Ruhr, Germany) was added when required. For microtiter plate cultivation, $1250 \mu \mathrm{L}$ of minimal medium was transferred to each well of a 48 Well FlowerPlate ${ }^{\circledR}(\mathrm{m} 2 \mathrm{p}$-labs, Baesweiler, Germany) with optodes for $\mathrm{pH}$ and DO. Plates were covered with an adhesive gas-permeable membrane (Thermo Scientific, Dreieich, Germany) and incubated in a BioLector ${ }^{\circledR}$ unit (m2p-labs, Baesweiler, Germany) at $37{ }^{\circ} \mathrm{C}$ and $1000 \mathrm{~min}^{-1}$ with an orbital shaking diameter of $3 \mathrm{~mm}$. The calibration values for the measurement of $\mathrm{pH}$ and DO were obtained from calibration data sheets provided by m2p-labs. According to manufacturer (m2plabs, Baesweiler, Germany), the oxygen transfer rate in 48 Well FlowerPlates ${ }^{\circledR}$ comes to $35-40 \mathrm{mmol} \mathrm{L}^{-1} \mathrm{~h}^{-1}$ for the used conditions (see above).

Samples of cultivation supernatant were taken for HPLC analysis (fructose, xylose and acetate) as well as for quantitative ELISA test (D1.3 scFv) as described below. For this, cell suspension (1-2 mL) was centrifuged at $9000 \times g, 5 \mathrm{~min}, 4{ }^{\circ} \mathrm{C}$. Sterile filtered (polyvinylidene 
fluoride, $0.2 \mu \mathrm{m}$ pore size, Roth, Karlsruhe, Germany) supernatant was stored at $-20{ }^{\circ} \mathrm{C}$.

Cultivation of all plasmid strains for the secretion of recombinant penicillin $\mathrm{G}$ acylase was performed in shake flasks as described for the production of D1.3 scFv above but took place in LB medium [81]. Main cultivations were performed in duplicates. Samples of cultivation supernatant were taken for penicillin $\mathrm{G}$ acylase activity assay as described below. For this, $1 \mathrm{~mL}$ cell suspension was centrifuged $\left(9000 \times g, 5 \mathrm{~min}, 4{ }^{\circ} \mathrm{C}\right)$, supernatant was filtered (polyvinylidene fluoride, $0.2 \mu \mathrm{m}$ pore size, Roth, Karlsruhe, Germany) and stored at $4{ }^{\circ} \mathrm{C}$ before use.

\section{$\mathrm{OD}_{600}$ and cell dry weight}

Cell concentration was determined as optical density at a wavelength of $600 \mathrm{~nm}$ using a Libra S11 Visible Spectrophotometer (Biochrom GmbH, Berlin, Germany). Cell dry weight $(\mathrm{CDW})$ was measured via gravimetric analysis. Here, $20 \mathrm{~mL}$ culture volume (duplicate) were pelleted $\left(1500 \times g, 15 \mathrm{~min}, 4{ }^{\circ} \mathrm{C}\right)$ in Corex glass tubes, washed twice with distilled water to remove salts and dried at $80{ }^{\circ} \mathrm{C}$ for $48 \mathrm{~h}$. The relationship between $\mathrm{CDW}$ and $\mathrm{OD}_{600}$ was determined as $\mathrm{CDW}\left[\mathrm{g} \mathrm{L}^{-1}\right]=a\left[\mathrm{~g} \mathrm{~L}^{-1}\right] \cdot \mathrm{OD}_{600}[-]$ with coefficient $a$ equals $0.223 \pm 0.007 \mathrm{~g} \mathrm{~L}^{-1}$ (B. megaterium MS941), $0.40 \pm 0.01 \mathrm{~g} \mathrm{~L}^{-1}$ (B. licheniformis MW3) and $0.337 \pm 0.002 \mathrm{~g} \mathrm{~L}^{-1}$ (all B. subtilis strains used in this study), respectively.

\section{High performance liquid chromatography (HPLC) analysis} Sugars (xylose, fructose) were quantified by an HPLC system (HitachiElite LaChrom, Krefeld, Germany) equipped with a Metacarb $87{ }^{\circ} \mathrm{C}$ column (Varian, Palo Alto, CA, USA) as stationary phase and Millipore $\mathrm{H}_{2} \mathrm{O}$ as mobile phase at $0.6 \mathrm{~mL} \mathrm{~min}{ }^{-1}$ and $85{ }^{\circ} \mathrm{C}$ with a retention time of approximately $11.7 \mathrm{~min}$ (xylose) and $13.4 \mathrm{~min}$ (fructose). Detection was performed using a refractive index detector (RI) detector. Acetate were also measured using an HPLC system (Hitachi Elite LaChrom, Krefeld, Germany) equipped with an Aminex HPX $87 \mathrm{H}$ column (Biorad, Hercules, CA, USA) as the stationary phase and $12.5 \mathrm{mM} \mathrm{H}_{2} \mathrm{SO}_{4}$ as mobile phase at $0.5 \mathrm{~mL} \mathrm{~min}^{-1}$ and $45{ }^{\circ} \mathrm{C}$ with a retention time of approximately $18.5 \mathrm{~min}$. Detection was performed using a RI detector.

\section{Enzyme-linked immunosorbent assay (ELISA)}

ELISA was used to quantify recombinant D1.3 scFv in the culture supernatant. Nunc MaxiSorp ${ }^{\circledR}$ flat-bottom 96 well plates (Nunc, Wiesbaden, Germany) were coated with $100 \mu \mathrm{L}$ of $10 \mathrm{mg} \mathrm{L}^{-1}$ hen egg white lysozyme in PBS buffer $\left(145 \mathrm{mM} \mathrm{NaCl}, 7.5 \mathrm{mM} \mathrm{Na}_{2} \mathrm{HPO}_{4} \cdot 2 \mathrm{H}_{2} \mathrm{O}\right.$ and $2.2 \mathrm{mM}$ $\mathrm{NaH}_{2} \mathrm{PO}_{4} \cdot 2 \mathrm{H}_{2} \mathrm{O}$ ) per well overnight at $4{ }^{\circ} \mathrm{C}$. Coated wells were washed three times with $100 \mu \mathrm{L}$ of PBS-T $0.05 \%$ [0.05\% (v/v) Tween 20 in PBS] and blocked with $2 \mathrm{~g} \mathrm{~L}^{-1}$ skim milk powder in PBS-T $0.1 \%[0.1 \%(\mathrm{v} / \mathrm{v})$ Tween 20 in PBS] for $1.5 \mathrm{~h}$, followed by three times washing with $100 \mu \mathrm{L}$ PBS-T $0.05 \%$. Samples of $100 \mu \mathrm{L}$ were incubated for $1.5 \mathrm{~h}$, followed by three times washing with $100 \mu \mathrm{L}$ of PBS-T 0.05\%. Detection was performed with $100 \mu \mathrm{L}$ of monoclonal Mouse anti penta His HRP conjugate (0.1 ng $\mu \mathrm{L}^{-1}$ in PBS-T 0.1\%) and visualized with $100 \mu \mathrm{L}$ of tetramethylbenzidine (TMB) substrate solution. Substrate solution consisted of 10 parts of TMB-A solution ( $3 \mathrm{mM} \mathrm{H}_{2} \mathrm{O}_{2}$ and $200 \mathrm{mM}$ potassium citrate at $\mathrm{pH} 4$ )

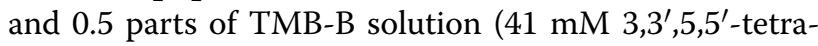
methylbenzidine in DMSO). The staining reaction was stopped by adding $100 \mu \mathrm{L}$ of $1 \mathrm{M} \mathrm{H}_{2} \mathrm{SO}_{4}$. The absorbance at $450 \mathrm{~nm}$ and scattered light at $620 \mathrm{~nm}$ were measured using a microtiter plate reader (SUNRISE, Tecan, Crailsheim, Germany). The absorbance at $620 \mathrm{~nm}$ was subtracted.

On each plate, a calibration standard of purified D1.3 scFv was applied. Standards were purified from culture supernatant with immobilized metal affinity chromatography (IMAC) and quantified by densiotometric analysis as described below. Samples for ELISA were measured in adequate dilutions (with PBS) and quantified according to the standard via five-parameter logistic analysis.

\section{Penicillin $\mathrm{G}$ acylase activity assay}

$100 \mu \mathrm{L}$ of substrate solution $\left(0.6 \mathrm{~g} \mathrm{~L}^{-1}\right.$ of synthetic substrate 2-nitro-5-[(phenylacetyl)amino]-benzoic acid, $9.41 \mathrm{mM} \mathrm{NaH} \mathrm{PO}_{4}, 40.59 \mathrm{mM} \mathrm{Na}_{2} \mathrm{HPO}_{4}, \mathrm{pH}$ 7.5) were added into a QS ultra-micro cuvette $(10 \mathrm{~mm}$ light pass; Hellma Analytics, Müllheim, Germany) in a tempered $\left(37{ }^{\circ} \mathrm{C}\right)$ cuvette holder of an UV-Vis spectrometer (Jasco V-650, Jasco, Groß-Umstadt, Germany). Addition of $11.11 \mu \mathrm{L}$ of pre-warmed $\left(37{ }^{\circ} \mathrm{C}\right)$ cell-free supernatant started the enzymatic reaction to 2-nitro5 -aminobenzoic acid, absorbing at $405 \mathrm{~nm}$ (extinction coefficient $\varepsilon$ of $\left.8.98 \mathrm{~cm}^{2} \mu \mathrm{mol}^{-1}\right)$. Change of absorption $\mathrm{dA} / \mathrm{dt}\left[\mathrm{min}^{-1}\right]$ at $405 \mathrm{~nm}$ was measured every second for $1 \mathrm{~min}$ and was used to calculate enzymatic activity EA $\left[\mu \mathrm{mol} \mathrm{cm}^{-3} \mathrm{~min}^{-1}\right.$ ]

$$
\mathrm{EA}=\frac{\frac{\mathrm{dA}}{\mathrm{dt}} \cdot \mathrm{V}_{\mathrm{R}}}{\varepsilon \cdot \mathrm{d} \cdot \mathrm{V}_{\mathrm{E}}}
$$

where, $V_{R}$ is the reaction volume $\left[\mathrm{cm}^{3}\right], V_{E}$ the sample volume $\left[\mathrm{cm}^{3}\right]$ and $\mathrm{d}$ equals the light pass $[\mathrm{mm}]$. Enzyme activity was expressed in $\mathrm{U} \mathrm{mL}^{-1}$ with one Unit $U$ equals the enzyme amount to convert $1 \mu \mathrm{mol}$ of 2-nitro-5[(phenylacetyl)amino]-benzoic acid per minute at $37^{\circ} \mathrm{C}$. 
Immobilized metal affinity chromatography (IMAC), sodium dodecyl sulfate polyacrylamide gel electrophoresis (SDS-PAGE) and densiotometric analysis

Recombinant D1.3 scFv was purified via IMAC. For this purpose a gravity flow column (BIORAD, Hercules, California, USA) was loaded with $1 \mathrm{~mL}$ Chelating Sepharose Fast Flow (Amersham Biosciences, Freiburg, Germany), washed with $10 \mathrm{~mL} \mathrm{H}_{2} \mathrm{O}$, incubated with $2 \mathrm{~mL} 100 \mathrm{mM} \mathrm{NiSO}_{4}$ for $10 \mathrm{~min}$ and washed with $5 \mathrm{~mL} \mathrm{H}_{2} \mathrm{O}$ followed by $5 \mathrm{~mL}$ washing buffer ( $50 \mathrm{mM} \mathrm{NaCl}, 20 \mathrm{mM}$ Tris- $\mathrm{HCl} \mathrm{pH} \mathrm{8.6).} \mathrm{The} \mathrm{nickel} \mathrm{charged}$ Sepharose was transferred to $50-100 \mathrm{~mL}$ of culture supernatant containing $7 \mathrm{mM}$ of imidazole and mixed for $90 \mathrm{~min}$ at $4{ }^{\circ} \mathrm{C}$. The Sepharose was pelleted by centrifugation $(1500 \times g$, $5 \mathrm{~min}, 4^{\circ} \mathrm{C}$ ) and washed with $3 \mathrm{~mL}$ washing buffer. Elution was performed with $3 \times 1 \mathrm{~mL}$ elution buffer (50 mM EDTA in washing buffer). $18 \mu \mathrm{L}$ of each fractions were analyzed by SDS-PAGE analysis (12\% of acrylamide) as described before [83]. Gels were stained with SimplyBlue ${ }^{\mathrm{TM}}$ SafeStain according to the manufacturer's instructions for the microwave procedure (Thermo Fisher Scientific Inc., Waltham, Massachusetts, USA). Band visible on the stained SDS PAGE corresponding to recombinant D1.3 scFv in the elution fractions from IMAC were quantified by densitometric analysis (ImageJ 1.48v, National Institute of Health, Bethesda, USA) related to a BSA standard $\left(10-100 \mathrm{mg} \mathrm{L}^{-1}\right)$.

\section{Precipitation of extracellular proteins}

Extracellular proteins of $B$. megaterium and B. subtilis strains cultivated in shake flasks were precipitated by incubating $1.5 \mathrm{~mL}$ culture supernatant with $660 \mathrm{mg}$ $\left(\mathrm{NH}_{4}\right)_{2} \mathrm{SO}_{4}$ for $2 \mathrm{~h}$ at $4{ }^{\circ} \mathrm{C}$ in an overhead shaker. After centrifugation $\left(9000 \times g, 30 \mathrm{~min}, 4{ }^{\circ} \mathrm{C}\right)$, precipitated proteins were suspended in $80 \mu \mathrm{L}$ of $8 \mathrm{M}$ urea supplemented with $27 \mu \mathrm{L}$ of 4-times SDS loading buffer. $15 \mu \mathrm{L}$ of this were analyzed by SDS-PAGE as described above.

\section{Determination of the volumetric mass transfer coefficient $\left(k_{L} a\right)$ in bioreactors}

$k_{L} a$ value in bioreactors was determined with sulfite oxidation method, which based on oxidation of $\mathrm{Na}_{2} \mathrm{SO}_{3}$ to $\mathrm{Na}_{2} \mathrm{SO}_{4}$ by oxygen. Measurement was performed under cultivation conditions (described above) without cells. $40 \mathrm{mg} \mathrm{L}^{-1}$ of $\mathrm{Co}\left(\mathrm{NO}_{3}\right)_{2}$ were added as catalyst. DO was monitored online with an oxygen sensor (Visiferm DO 225, Hamilton, Höchst im Odenwald, Deutschland). Calibration to $100 \%$ was performed under oxygen saturation condition $\left(\mathrm{DO}_{\max }=6.784 \mathrm{mg} \mathrm{L} \mathrm{m}^{-1}\right.$ at $\left.37^{\circ} \mathrm{C}\right)$. Complete oxygen depletion was achieved by addition of $10 \mathrm{~mL}$ of a $200 \mathrm{~g} \mathrm{~L}^{-1} \mathrm{Na}_{2} \mathrm{SO}_{3}$ stock solution [84]. As soon as the oxidation was completed the DO increased again. Plotting $\ln \left(\mathrm{DO}_{\max }-\mathrm{DO}\right)$ against time, the linear slope was used to determine the $k_{L} a$ value.

\section{Kinetics analysis of D1.3 scFv production}

The Luedeking-Piret model was used for modeling the D1.3 scFv production and secretion [85]. The observed experimental product profile from cultivation start to the time point of maximal D1.3 $\mathrm{scFv}$ concentration was approximated by the numerical integration of the Luedeking-Piret equation

$$
P_{n}=P_{n-1}+\left(\alpha \cdot \frac{X_{n}-X_{n-1}}{t_{n}-t_{n-1}}+\beta \cdot X_{n}\right)\left(t_{n}-t_{n-1}\right) ;
$$

here, $t_{n}$ and $t_{n-1}$ are the present and previous time steps of integration. $P_{n}$ and $P_{n-1}$ are concentrations of the product D1.3 scFv and $X_{n}$ and $X_{n-1}$ the cell dry weights at the present and previous time steps. The growthassociated Luedeking-Piret constant $\alpha\left[\mathrm{mg}_{\text {scFv }} \mathrm{g}_{\text {cells }}^{-1}\right.$ ] equals the biomass-related product yield coefficient $\mathrm{Y}_{\mathrm{P} / \mathrm{X}}$ for D1.3 scFv formation. The non-growth-associated Luedeking-Piret constant $\beta\left[\mathrm{mg}_{\mathrm{scFv}} \mathrm{g}_{\text {cells }}^{-1} \mathrm{~h}^{-1}\right]$ represents the specific production rate for specific growth rate $\mu=0 \mathrm{~h}^{-1}$. These biological reaction parameters were set so that the coefficient of determination $R^{2}$ was maximal, representing the goodness of fit of the model concentrations of D1.3 scFv compared to the experimental concentrations. Calculation was performed with the Generalized Reduced Gradient algorithm of the addin program Solver for Microsoft Excel 2010 (Microsoft, Redmund, WA, USA).

\section{Additional file}

Additional file 1. Additional tables and figures.

\section{Abbreviations}

$a\left(\equiv Y_{P / X}\right)$ : growth-associated Luedeking-Piret constant and biomass related product yield coefficient $\left[\mathrm{mg}_{\mathrm{scFv}} \mathrm{g}_{\text {cells }}^{-1}\right] ;$ : non-growth-associated specific production rate for specific growth rate $\mu=0\left[\mathrm{mg}_{\mathrm{scFv}} \mathrm{g}_{\text {cells }}^{-1} \mathrm{~h}^{-\dagger}\right] ; B$. megaterium: Bacillus megaterium (for B. licheniformis and B. subtilis as well); CDW: cell dry weight [ $\mathrm{g} \mathrm{L}^{-1}$ ]; DO: dissolved oxygen [\%]; ELISA: enzyme-linked immunosorbent assay; HPLC: high-performance liquid chromatography; $k_{1} a$ : volumetric oxygen transfer coefficient $\left[\mathrm{h}^{-1}\right]$; $\mu$ : specific growth rate $\left[\mathrm{h}^{-1}\right]$; OTR: oxygen transfer rate $\left[\mathrm{mg} \mathrm{L}^{-1} \mathrm{~h}^{-1}\right.$ ]; P: concentration of the product D1.3 sCFv; sCFv: single-chain fragment variable; SDS-PAGE: sodium dodecyl sulfate polyacrylamide gel electrophoresis; STY: space-time-yield $\left[\mathrm{mg}_{\mathrm{scFv}} \mathrm{L}^{-1} \mathrm{~h}^{-1}\right]$; t: time $[\mathrm{h}] ; \mathrm{X}$ : cell concentration (cell dry weight) $\left[\mathrm{g} \mathrm{L}^{-1}\right] ; Y_{\mathrm{p} / \mathrm{X}}$ : biomass related product yield coefficient $\left[\mathrm{mg}_{\mathrm{scFv}} \mathrm{g}_{\mathrm{cells}}^{-1}\right]$.

\section{Authors' contributions}

AL carried out transformation, cultivation experiments and analytics. RB constructed the plasmid pRBBm117. RB and RK conceived of the study and participated in its design and coordination. All authors read and approved the final manuscript.

\section{Author details}

${ }^{1}$ Institute of Biochemical Engineering, Technische Universität Braunschweig, Rebenring 56, 38106 Braunschweig, Germany. ${ }^{2}$ Center of Pharmaceutical Engineering (PVZ), Technische Universität Braunschweig, Franz-List-Straße 35a, 38106 Braunschweig, Germany. ${ }^{3}$ Braunschweig Centre of Systems Biology (BRICS), Technische Universität Braunschweig, Rebenring 56, 38106 Braunschweig, Germany. ${ }^{4}$ Institute of Microbiology, Technische Universität Braunschweig, Rebenring 56, 38106 Braunschweig, Germany. 


\section{Acknowledgements}

The authors acknowledge financial support from the Lower Saxony Ministry for Science and Culture for PhD scholarship in the Graduate Schools Novel synthesis and formulation methods for poorly soluble drugs and sensitive biopharmaceuticals (SynFoBiA) within the Center of Pharmaceutical Engineering (PVZ), at the Technische Universität Braunschweig, Germany. The authors thank Stefan Dübel (Braunschweig, Germany) for providing the gene of the D1.3 scFv. B. licheniformis MW3 was kindly provided by Friedhelm Meinhardt (Münster, Germany). We are indebted to Dieter Jahn (BRICS, Braunschweig, Germany) for critically reading the manuscript and continuous support.

\section{Competing interests}

The authors declare that they have no competing interests.

\section{Availability of data and supporting materials}

The datasets supporting the conclusions of this article are included within the article and its additional files.

\section{Funding}

The investigations on recombinant production of the antibody fragment D1.3 scFv with different Bacillus strains were funded by the regional government of Lower Saxony Ministry for Science and Culture, Germany.

Received: 18 October 2016 Accepted: 4 January 2017

Published online: 23 January 2017

\section{References}

1. Harwood CR, editor. Bacillus. New York: Plenum Press; 1989

2. Doi RH, McGloughlin M, editors. Biology of Bacilli: applications to industry. Boston: Butterworth-Heinemann; 1992.

3. Schallmey M, Singh A, Ward OP. Developments in the use of Bacillus species for industrial production. Can J Microbiol. 2004;50:1-17.

4. Katz E, Demain AL. The peptide antibiotics of Bacillus: chemistry, biogenesis, and possible functions. Bacteriol Rev. 1977:41:449-74.

5. Bishop A. Bacillus thuringiensis insecticides. In: Berkeley R, Heyndrickx M, Logan N, De Vos P, editors. Applications and systems of Bacillus and relatives. Oxford: Blackwell Science Ltd; 2002. p. 160-75.

6. Phelps RJ, McKillip JL. Enterotoxin production in natural isolates of Bacillaceae outside the Bacillus cereus group. Appl Environ Microbiol. 2002;68:3147-51.

7. Perkins BJ, Sloma A, Hermann T, Theriault K, Zachgo E, Erdenberger T, Hannett N, Chatterjee PN, Williams V II, Hatch R, Pero J. Genetic engineering of Bacillus subtilis for the commercial production of riboflavin. J Ind Microbiol Biotechnol. 1999;22:8-18.

8. Manocha B, Margaritis A. A novel Method for the selective recovery and purification of $\gamma$-polyglutamic acid from Bacillus licheniformis fermentation broth. Biotechnol Prog. 2010;26:734-42.

9. Hoennscheidt C, Margaritis A, Krull R. Novel applications of ubiquinone biopolymer nanocarriers for preventive and regenerative therapeutics: the Saccharomyces cerevisiae paradigm. Int J Pharm. 2015;478:416-25.

10. GRAS Notices No. 562. US Food and Drug Administration. http://www. accessdata.fda.gov/scripts/fdcc/?set $=$ GRASNotices\&id $=562 \&$ sort $=$ GRN_No\&order=DESC\&startrow $=1 \&$ type $=$ basic\&search $=$ bacillus $\% 20$ subtilis. Accessed 27 June 2016.

11. GRAS Notices No. 560. US Food and Drug Administration. http://www accessdata.fda.gov/scripts/fdcc/?set=GRASNotices\&id $=560 \&$ sort $=$ GRN_No\&order=DESC\&startrow=1\&type=basic\&search=bacillus $\% 20$ licheniformis. Accessed 27 June 2016.

12. Harwood CR. Bacillus subtilis and its relatives: molecular biological and industrial workhorses. Trends Biotechnol. 1992;10:247-56.

13. Breitling R, Gerlach D, Hartmann M, Behnke D. Secretory expression in Escherichia coli and Bacillus subtilis of human interferon alpha genes directed by staphylokinase signals. Mol Gen Genet. 1989;217:384-91.

14. Honjo M, Nakayama A, lio A, Mita I, Kawamura K, Sawakura A, Furutani Y. Construction of a highly efficient host-vector system for secretion of heterologous protein in Bacillus subtilis. J Biotechnol. 1987;6:191-204.
15. Yamagata H, Nakahama K, Suzuki Y, Kakinuma A, Tsukagoshi N, Udaka S. Use of Bacillus brevis for efficient synthesis and secretion of human epidermal growth factor. Proc Natl Acad Sci USA. 1989;86:3589-93.

16. Simonen M, Palva I. Protein secretion in Bacillus species. Microbiol Rev. 1993:57:109-37.

17. Doi RH, Wong S-L, Kawamura F. Potential use of Bacillus subtilis for secretion and production of foreign proteins. Trends Biotechnol. 1986:4:232-5.

18. Park S, Schumann W. Optimization of the secretion pathway for heterologous proteins in Bacillus subtilis. Biotechnol Bioprocess Eng. 2015;20:623-33.

19. Sarvas M, Harwood CR, Bron S, van Dijl JM. Post-translocational folding of secretory proteins in Gram-positive bacteria. Biochim Biophys Acta. 2004;1694:311-27.

20. Nagarajan V. Protein Secretion. In: Sonenshein AL, Losick R, Hoch JA, editors. Bacillus subtilis and other Gram-positive bacteria. Washington: American Society of Microbiology; 1993. p. 713-26.

21. Westers L, Westers H, Quax WJ. Bacillus subtilis as cell factory for pharmaceutical proteins: a biotechnological approach to optimize the host organism. Biochim Biophys Acta. 2004;1694:299-310.

22. Dübel S, Reichert JM, editors. Handbook of therapeutic antibodies. 2nd ed. Weinheim: Wiley Blackwell; 2014.

23. Weisser NE, Hall JC. Applications of single-chain variable fragment antibodies in therapeutics and diagnostics. Biotechnol Adv. 2009:27:502-20.

24. Dahan S, Chevet E, Liu J-F, Dominguez M. Antibody-based proteomics: from bench to bedside. PROTEOMICS Clin Appl. 2007;1:922-33.

25. Edelman GM. Antibody structure and molecular immunology. Science. 1973; 180:830-40.

26. Frenzel A, Hust M, Schirrmann T. Expression of recombinant antibodies. Front Immunol. 2013;4:1-20.

27. Padlan EA. Anatomy of the antibody molecule. Mol Immunol. 1994;31:169-217

28. Bird RE, Hardman KD, Jacobson JW, Johnson S, Kaufman BM, Lee SM, Pope SH, Riodan GS, Whitlow M. Single-chain antigen-binding proteins. Science. 1988:242:423-6.

29. Chandel AK, Rao LV, Narasu ML, Singh OV. The realm of penicillin G acylase in $\beta$-lactam antibiotics. Enzyme Microb Technol. 2008;42:199-207.

30. Yang S, Huang Y-H, Huang X-D, Li S-Y, Yuan Z-Y. High expression of penicillin $\mathrm{G}$ acylase gene from Bacillus megaterium in Bacillus subtilis. Acta Biochim Biophys Sin. 1999;31:602-3.

31. Kasche V, Lummer K, Nurk A, Piotraschke E, Rieks A, Stoeva S, Voelter W. Intramolecular autoproteolysis initiates the maturation of penicillin amidase from Escherichia coli. Biochim Biophys Acta. 1999;1433:76-86.

32. Stammen S, Müller BK, Korneli C, Biedendieck R, Gamer M, Franco-Lara E, Jahn D. High-yield intra- and extracellular protein production using Bacillus megaterium. Appl Environ Microbiol. 2010:76:4037-46.

33. Jordan E, Hust M, Roth A, Biedendieck R, Schirrmann T, Jahn D, Dübel S. Production of recombinant antibody fragments in Bacillus megaterium. Microb Cell Fact. 2007;6:1-11.

34. Bernhard K, Schrempf H, Goebel W. Bacteriocin and antibiotic resistance plasmids in Bacillus cereus and Bacillus subtilis. J Bacteriol. 1978;133:897-903.

35. Cheah UE, Weigand WA, Stark BC. Effects of recombinant plasmid size on cellular processes in Escherichia coli. Plasmid. 1987;18:127-34.

36. Wittchen K-D, Meinhardt F. Inactivation of the major extracellular protease from Bacillus megaterium DSM319 by gene replacement. Appl Microbiol Biotechnol. 1995:42:871-7.

37. Schiefelbein S, Fröhlich A, John GT, Beutler F, Wittmann C, Becker J. Oxygen supply in disposable shake-flasks: prediction of oxygen transfer rate, oxygen saturation and maximum cell concentration during aerobic growth. Biotechnol Lett. 2013;35:1223-30.

38. Klöckner W, Büchs J. Advances in shaking technologies. Trends Biotechnol. 2012:30:307-14.

39. Rygus T, Hillen W. Inducible high-level expression of heterologous genes in Bacillus megaterium using the regulatory elements of the xylose-utilization operon. Appl Microbiol Biotechnol. 1991:35:594-9.

40. David F, Steinwand M, Hust M, Bohle K, Ross A, Dübel S, Franco-Lara E. Antibody production in Bacillus megaterium: strategies and physiological implications of scaling from microtiter plates to industrial bioreactors. Biotechnol J. 2011;6:1516-31.

41. Duetz WA. Microtiter plates as mini-bioreactors: miniaturization of fermentation methods. Trends Microbiol. 2007:15:469-75. 
42. Liu H-S, Chiung W-C, Wang Y-C. Effect of lard oil, olive oil and castor oil on oxygen transfer in an agitated fermentor. Biotechnol Tech. 1994;8:17-20.

43. Morão A, Maia Cl, Fonseca MMR, Vasconcelos JMT, Alves SS. Effect of antifoam addition on gas-liquid mass transfer in stirred fermenters. Bioprocess Eng. 1999;20:165.

44. Wolfe AJ. The acetate switch. Microbiol Mol Biol Rev. 2005;69:12-50.

45. Korneli C, David F, Godard T, Franco-Lara E. Influence of fructose and oxygen gradients on fed-batch recombinant protein production using Bacillus megaterium. Eng Life Sci. 2011;11:338-49.

46. Scheler A, Hillen W. Regulation of xylose utilization in Bacillus licheniformis: $x y l$ repressor-xyl-operator interaction studied by DNA modification protection and interference. Mol Microbiol. 1994;13:505-12.

47. Waschkau B, Waldeck J, Wieland S, Eichstädt R, Meinhardt F. Generation of readily transformable Bacillus licheniformis mutants. Appl Microbiol Biotechnol. 2008;78:181-8.

48. Paczia N, Nilgen A, Lehmann T, Gätgens J, Wiechert W, Noack S. Extensive exometabolome analysis reveals extended overflow metabolism in various microorganisms. Microb Cell Fact. 2012:11:122

49. Scheler A, Rygus T, Allmansberger R, Hillen W. Molecular cloning, structure, promoters and regulatory elements for transcription of the Bacillus licheniformis encoded regulon for xylose utilization. Arch Microbiol. 1991:155:526-34

50. Veith B, Herzberg C, Steckel S, Feesche J, Maurer KH, Ehrenreich P, Bäumer S, Henne A, Liesgang H, Merkl R, Ehrenreich A, Gottschalk G. The complete genome sequence of Bacillus licheniformis DSM13, an organism with great industrial potential. J Mol Microbiol Biotechnol. 2004;7:204-11.

51. Burkholder PR, Giles NH. Induced biochemical mutations in Bacillus subtilis. Am J Bot. 1947;34:345-8.

52. Doi RH, He X-S, McCready P, Bakheit N. Bacillus subtilis: a model system for heterologous gene expression. In: Kelly JW, Baldwin TO, editors. Application of enzyme biotechnology. Boston: Springer US; 1991. p. 261-272.

53. Wu S-C, Yeung JC, Duan Y, Ye R, Szarka SJ, Habibi HR, Wong SL. Functional production and characterization of a fibrin-specific single-chain antibody fragment from Bacillus subtilis: effects of molecular chaperones and a wall-bound protease on antibody fragment production. Appl Environ Microbiol. 2002;68:3261-9.

54. Nguyen HD, Phan TTP, Schumann W. Analysis and application of Bacillus subtilis sortases to anchor recombinant proteins on the cell wall. AMB Express. 2011;1:22.

55. Kunst F, Ogasawara N, Moszer I, Albertini AM, Alloni G, Azevedo V, Bertero MG, Bessieres P, Bolotin A, Borchert S. The complete genome sequence of the Gram-positive bacterium Bacillus subtilis. Nature. 1997:390:249-56.

56. Schmiedel D, Hillen W. A Bacillus subtilis 168 mutant with increased xylose uptake can utilize xylose as sole carbon source. FEMS Microbiol Lett. 1996;135:175-8

57. Kim L, Mogk A, Schumann W. A xylose-inducible Bacillus subtilis integration vector and its application. Gene. 1996;181:71-6.

58. Zayas JF. Foaming properties of proteins. In: Zayas JF, editor. Functionality of proteins in food. Berlin: Springer; 1997. p. 260-309.

59. Speck E, Freese E. Control of metabolite secretion in Bacillus subtilis. Microbiology. 1973;78:261-75.

60. Wu X-C, Ng S-C, Near Rl, Wong S-L. Efficient production of a functional single-chain antidigoxin antibody via an engineered Bacillus subtilis expression-secretion system. Biotechnology. 1993;11:71-6.

61. Routledge SJ. Beyond de-foaming: the effects of antifoams on bioprocess productivity. Comput Struct Biotechnol J. 2012;3:1-7.

62. He X-S, Brückner R, Doi RH. The protease genes of Bacillus subtilis. Res Microbiol. 1991;142:797-803.

63. Malten M, Biedendieck R, Gamer M, Drews A-C, Stammen S, Buchholz K, Dijkhuizen L, Jahn D. A Bacillus megaterium plasmid system for the production, export, and one-step purification of affinity-tagged heterologous levansucrase from growth medium. Appl Environ Microbiol. 2006;72:1677-9.

64. Jordan E, Al-Halabi L, Schirrmann T, Hust M, Dübel S. Production of single chain Fab (scFab) fragments in Bacillus megaterium. Microb Cell Fact. 2007;6:1.

65. David F Westphal R, Bunk B, Jahn D, Franco-Lara E Optimization of antibody fragment production in Bacillus megaterium: the role of metal ions on protein secretion. J Biotechnol. 2010;150:115-24.

66. Miethe S, Meyer T, Wöhl-Bruhn S, Frenzel A, Schirrmann T, Dübel S, Hust M. Production of single chain fragment variable (scFv) antibodies in Escherichia coli using the LEX ${ }^{\mathrm{TM}}$ bioreactor. J Biotechnol. 2013;163:105-11.
67. Wu S-C, Ye R, Wu X-C, Ng S-C, Wong S-L. Enhanced secretory production of a single-chain antibody fragment from Bacillus subtilis by coproduction of molecular chaperones. J Bacteriol. 1998;180:2830-5.

68. Inoue Y, Ohta T, Tada H, Iwasa S, Udaka S, Yamagata H. Efficient production of a functional mouse/human chimeric Fab'against human urokinase-type plasminogen activator by Bacillus brevis. Appl Microbiol Biotechnol. 1997:48:487-92.

69. Krüger C, Hu Y, Pan Q, Marcotte H, Hultberg A, Delwar D, van Dalen PJ, Pouwels PH, Lee RJ, Kelly CG. In situ delivery of passive immunity by lactobacilli producing single-chain antibodies. Nat Biotechnol. 2002:20:702-6

70. Hoang PM, Cho S, Kim KE, Byun SJ, Lee T-K, Lee S. Development of Lactobacillus paracasei harboring nucleic acid-hydrolyzing 3D8 scFv as a preventive probiotic against murine norovirus infection. Appl Microbiol Biotechnol. 2015;99:2793-803.

71. Pant N, Hultberg A, Zhao Y, Svensson L, Pan-Hammarström Q, Johansen K, Pouwels PH, Ruggeri FM, Hermans P, Frenken L. Lactobacilli expressing variable domain of llama heavy-chain antibody fragments (lactobodies) confer protection against rotavirus-induced diarrhea. J Infect Dis. 2006:194:1580-8.

72. Jones D, Kroos N, Anema R, Van Montfort B, Vooys A, van der Kraats S, van der Helm E, Smits S, Shouten J, Brouwer K, Lagerwerf F, Van Berkel P, Opstelten DJ, Logtenberg T, Bout A. High-level expression of recombinant IgG in the human cell line PER.C6. Biotechnol Prog. 2003;19:163-8.

73. Burky JE, Wesson MC, Young A, Farnsworth S, Dionne B, Zhu Y, Hartman TE, Qu L, Zhou W, Sauer PW. Protein-free fed-batch culture of non-GS NSO cell lines for production of recombinant antibodies. Biotechnol Bioeng. 2007;96:281-93.

74. Wurm FM. Production of recombinant protein therapeutics in cultivated mammalian cells. Nat Biotechnol. 2004;22:1393-8.

75. Birch JR, Racher AJ. Antibody production. Adv Drug Deliv Rev. 2006;58:671-85.

76. Kober L, Zehe C, Bode J. Optimized signal peptides for the development of high expressing CHO cell lines. Biotechnol Bioeng. 2013;1 10:1 164-73.

77. Chen X-A, Cen P-L. A novel three-stage process for continuous production of penicillin $\mathrm{G}$ acylase by a temperature-sensitive expression system of Bacillus subtilis phage phi105. Chem Biochem Eng Q. 2005;19:367-72.

78. Kang JH, Hwang Y, Yoo OJ. Expression of penicillin $\mathrm{G}$ acylase gene from Bacillus megaterium ATCC 14945 in Escherichia coli and Bacillus subtilis. J Biotechnol. 1991:17:99-108.

79. Zhu F-M, Ji S-Y, Zhang W-W, Li W, Cao B-Y, Yang M-M. Development and application of a novel signal peptide probe vector with PGA as Reporter in Bacillus subtilis WB700: twenty-four tat pathway signal peptides from Bacillus subtilis were monitored. Mol Biotechnol. 2008:39:225-30.

80. Eppinger M, Bunk B, Johns MA, Edirisinghe JN, Kutumbaka KK, Koenig SSK, Huot CH, Rosovitz MJ, Riley DR, Daugherty S, Martin M, Elbourne LDH, Paulsen I, Biedendieck R, Braun C, Grayburn S, Dhingra S, Lukyanchuk V, Ball B, UI-Qamar R, Seibel J, Bremer E, Jahn D, Ravel J, Vary PS. Genome sequences of the biotechnologically important Bacillus megaterium strains QM B1551 and DSM319. J Bacteriol. 2011;193:4199-213.

81. Sambrook J, Russell DW. Molecular cloning: a laboratory manual. 3rd ed. Cold Spring Harbor: Cold Spring Harbor Laboratory Press; 2001.

82. Biedendieck R, Borgmeier C, Bunk B, Stammen S, Scherling C, Meinhardt F, Wittmann C, Jahn D. Systems biology of recombinant protein production using Bacillus megaterium. Methods Enzymol. 2011:500:165-95.

83. Righetti PG, Gianazza E, Gelfi C, Chairi M. In: Hames BD, Rickwood D, editors. Gel Electrophoresis of proteins: a practical approach. 2 nd ed. New York: IRL Press at Oxford University Press; 1990. p. 149-214.

84. Hermann R, Walther N, Maier U, Büchs J. Optical method for the determination of the oxygen-transfer capacity of small bioreactors based on sulfite oxidation. Biotechnol Bioeng. 2001;74:355-63.

85. Luedeking R, Piret EL. A kinetic study of the lactic acid fermentation Batch process at controlled pH. J Biochem Microbiol Technol Eng. 1959;1:393-412. 